Review

\title{
Supercritical Carbon Dioxide-Based Processes in Photocatalytic Applications
}

\author{
Paola Franco ${ }^{1}$, Olga Sacco ${ }^{2}\left(\mathbb{D}\right.$, Vincenzo Vaiano ${ }^{1}(\mathbb{D})$ and Iolanda De Marco ${ }^{1,3, * \mathbb{D}}$ \\ 1 Department of Industrial Engineering, University of Salerno, Via Giovanni Paolo II, 132, 84084 Fisciano, Italy; \\ pfranco@unisa.it (P.F.); vvaiano@unisa.it (V.V.) \\ 2 Department of Chemistry and Biology "A. Zambelli", University of Salerno, Via Giovanni Paolo II, 132, \\ 84084 Fisciano, Italy; osacco@unisa.it \\ 3 Research Centre for Biomaterials BIONAM, University of Salerno, Via Giovanni Paolo II, 132, \\ 84084 Fisciano, Italy \\ * Correspondence: idemarco@unisa.it; Tel.: +39-089-964066
}

Citation: Franco, P.; Sacco, O.;

Vaiano, V.; De Marco, I. Supercritical Carbon Dioxide-Based Processes in Photocatalytic Applications. Molecules 2021, 26, 2640. https://doi.org/10.3390/ molecules 26092640

Academic Editors: Mauro Banchero and Barbara Onida

Received: 2 April 2021

Accepted: 28 April 2021

Published: 30 April 2021

Publisher's Note: MDPI stays neutral with regard to jurisdictional claims in published maps and institutional affiliations.

Copyright: (c) 2021 by the authors. Licensee MDPI, Basel, Switzerland. This article is an open access article distributed under the terms and conditions of the Creative Commons Attribution (CC BY) license (https:// creativecommons.org/licenses/by/ $4.0 /)$.

\begin{abstract}
Conventional methods generally used to synthesize heterogeneous photocatalysts have some drawbacks, mainly the difficult control/preservation of catalysts' morphology, size or structure, which strongly affect the photocatalytic activity. Supercritical carbon dioxide $\left(\mathrm{scCO}_{2}\right)$-assisted techniques have recently been shown to be a promising approach to overcome these limitations, which are still a challenge. In addition, compared to traditional methods, these innovative techniques permit the synthesis of high-performance photocatalysts by reducing the use of toxic and polluting solvents and, consequently, the environmental impact of long-term catalyst preparation. Specifically, the versatility of $\mathrm{scCO}_{2}$ allows to prepare catalysts with different structures (e.g., nanoparticles or metal-loaded supports) by several supercritical processes for the photocatalytic degradation of various compounds. This is the first updated review on the use of $\mathrm{scCO}_{2}$-assisted techniques for photocatalytic applications. We hope this review provides useful information on different approaches and future perspectives.
\end{abstract}

Keywords: supercritical drying; supercritical antisolvent; supercritical impregnation; heterogeneous photocatalysis; air pollution; wastewater treatment

\section{Introduction}

Techniques based on the use of supercritical fluids have been used for more than 50 years because of their physicochemical properties, which are intermediate between a gas and a liquid and are easily adjustable with changes in temperature and pressure. Among the different fluids that are used at supercritical conditions; i.e., at pressures and temperatures higher than the critical values, carbon dioxide is the most employed one, because of its mild critical conditions $\left(T_{\mathrm{c}}=31.1{ }^{\circ} \mathrm{C}, P_{\mathrm{C}}=7.38 \mathrm{MPa}\right)$, its recyclability, cheapness, and low toxicity. Moreover, considering that carbon dioxide is a gas at room temperature and pressure, solvent-free products can be obtained after the depressurization at ambient pressure. Techniques based on the use of supercritical carbon dioxide $\left(\mathrm{scCO}_{2}\right)$ have been used as an alternative to different traditional processes such as extraction, micronization, impregnation, membrane and aerogel formation, electrospinning, electrospray and so on [1-5]. Considering the variety of techniques used, even the fields of application are among the most diverse, from pharmaceutical/biomedical [6-8] to food packaging $[9,10]$, and from dye processing $[11,12]$ to the catalytic field $[13,14]$.

Focusing on the catalytic field, it is possible to note that from same perspective of using environmentally friendly processes, the interest of the scientific community in heterogeneous photocatalysis (HP) has grown considerably. HP is an advanced oxidation process in which the inexhaustibly abundant, clean, and safe solar energy is converted and stored through reactions involving electron transfer. HP is a versatile, efficient, relatively cheap, 
and environmentally benign technology for decomposing various biological, organic, and inorganic pollutants present in low concentrations within the soil, water, and air $[15,16]$. Its main advantages are: (1) it is a good substitute for conventional energy-intensive treatments, considering that it uses renewable sources of energy and solar energy; (2) differently from conventional treatments, which transfer pollutants from a medium to another, harmless products are formed due to the photocatalytic reaction; (3) it can be applied to aqueous, gaseous and soil treatments; (4) its reaction conditions are mild, the reaction time is modest, and a small amount of chemical reagents is required [17].

The materials generally employed in photocatalysis are semiconductors with a typical band structure, roughly characterized by a valence band, which is the highest energy band in which all electronic levels are occupied by electrons and a conduction band, which is the lowest energy band not occupied by electrons [18,19]. The energy intervals between the electronically populated valence band and the vacant conduction band, called band gaps, constitute forbidden energy intervals, which electrons cannot assume [20]. The semi-conductive photocatalysts generally used are titanium dioxide or titania $\left(\mathrm{TiO}_{2}\right)$ [21-23], $\mathrm{ZnO}[24,25]$, $\mathrm{WO}_{3}[26,27], \mathrm{Fe}_{2} \mathrm{O}_{3}[28,29], \mathrm{CeO}_{2}[30,31], \mathrm{MoO}_{3}[32,33], \mathrm{ZrO}_{2}[34,35], \mathrm{SnO}_{2}[36,37], \mathrm{CdS}[38,39]$, and ZnS [40,41]. Up to now, semiconductor-based photocatalysts in various forms have been proposed, mainly as nanopowders [42-48] or aerogels [49-54], due to the high specific surface area of these materials, resulting in a very high contact between the semiconductor and the fluid to be treated and, consequently, the photocatalytic performance could be enhanced.

In recent years, the advantages of using processes based on the use of $\mathrm{scCO}_{2}$ have been exploited to obtain higher-performing photocatalysts for water and air purification. The environmental advantage resulting from the coupling of processes with a low environmental impact if compared to classical processes is undeniable. Indeed, several papers [55-57] have highlighted the potential of exploiting $\mathrm{scCO}_{2}$ in terms of catalytic and environmental performances mainly related to the replacement of hazardous, polluting and toxic organic solvents or reaction media.

To the best of our knowledge, no reviews have been published on the use of supercritical carbon dioxide-based techniques for obtaining photocatalysts. Therefore, the present review is organized by classifying the published papers according to the supercritical carbon dioxide-based process used to produce the photocatalyst. Indeed, different approaches have been investigated, such as supercritical deposition, supercritical antisolvent process to obtain nanoparticles, sol-gel reaction, supercritical drying, and others.

\section{Supercritical Deposition of Nano-Scale Metal-Organic Precursors}

Nanoparticles, nanorods, aerogels or thin films have been frequently used in photocatalysis because of the high surface-to-volume ratio of nanostructured materials. Metals and metal oxides can be dispersed as nanoparticles on both the external and the internal surface of support materials. Supercritical deposition has been attracting interest because of the peculiar properties of $\mathrm{scCO}_{2}$, such as solvent power adjustable with small variations in pressure and temperature, absence of liquid waste and solvent residue on the substrate, fast rates of deposition because of high mass transfer rates at supercritical conditions [58,59]. According to Watkins and McCarthy [60], it is possible to consider three subsequent steps (Figure 1):

1. The metal precursor is dissolved in $\mathrm{ScCO}_{2}$;

2. The metal precursor is adsorbed from the fluid phase to the support material or reacts with the surface of the support;

3. The adsorbed metal precursor is converted to its metal or metal oxide form. 


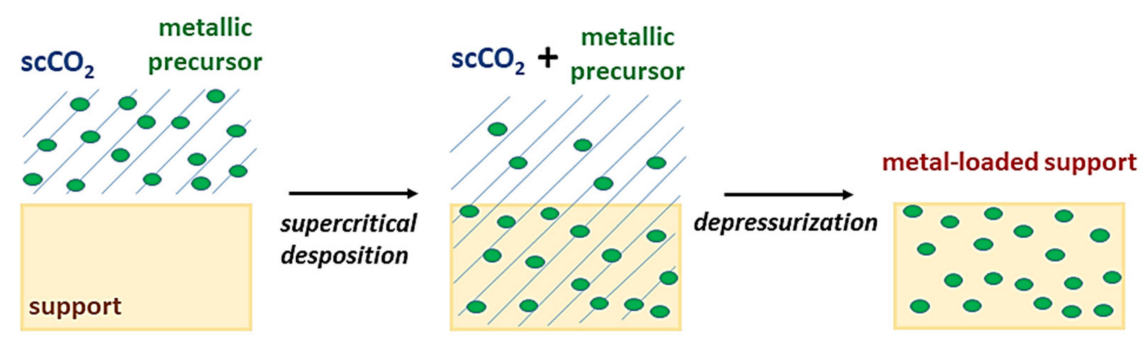

Figure 1. Sketch of supercritical deposition stages.

Watkins and McCarthy [60] also highlighted the numerous advantages in the preparation of polymer/metal nanocomposites using this supercritical approach. Specifically, a key aspect is the ability of the $\mathrm{scCO}_{2}$ to swell the polymeric substrates that, combined with the high $\mathrm{scCO}_{2}$ diffusivity, leads to high penetration of organic/organometallic reagents solubilized in $\mathrm{scCO}_{2}$ into the polymer matrix. The degree of polymer swelling and diffusion/transport properties can be modulated by varying the temperature and pressure, which strongly influence the density and the solvent power of $\mathrm{scCO}_{2}$. However, the polymer constituting the support as well as the reaction product has to be insoluble/poorlysoluble in the supercritical fluid. In addition, the use of $\mathrm{scCO}_{2}$ offers an outstanding control of the composites' morphology; e.g., it can allow the preservation of the porous structure of matrices, avoiding their collapse, or the spherical nanoparticle shape, with reduced sintering phenomena. Aiming at the photocatalytic degradation of methylene blue dye, Horibe et al. [61] loaded $\mathrm{TiO}_{2}$ nanoparticles on/in nanostructured-carbon walls by the supercritical deposition of titanium tetraisopropoxide (TTIP), which was selected as the organometallic precursor. Specifically, two reactions were involved in the formation of $\mathrm{TiO}_{2}$ : firstly, the decomposition of the precursor TTIP, followed by the dehydration of the intermediate obtained by the first stage. A better nucleation and growth of the nanoparticles on the carbon nanowalls surface occurred at $180^{\circ} \mathrm{C}$ with respect to $100^{\circ} \mathrm{C}$, leading to the attainment of a support in which the $\mathrm{TiO}_{2}$ nanoparticles were homogeneously dispersed.

Similarly, Liu et al. [62] and Kashiwaya et al. [63] prepared photocatalysts by supercritical decomposition, to be applied for the photocatalytic removal of two dyes, methylene blue, and methyl orange. In particular, Liu et al. [62] proposed a novel method of "supercritical deposition assisted by liquid-crystal template" to prepare nanocomposites consisting of mesoporous silica SBA- 15 coated with $\mathrm{TiO}_{2}$. Compared to the results obtained by coating the $\mathrm{TiO}_{2}$ on the surface of non-porous SBA-15 using a similar approach without template, mesoporous $\mathrm{TiO}_{2}$ coated SBA-15 showed a more uniform deposition and an improved degradation efficiency for azo dyes as well as phenol. In the study of Kashiwaya et al. [63], the $\mathrm{scCO}_{2}$ allowed to effectively impregnate nitrate nickel oxide $(\mathrm{NiO})$ nanoparticles, starting from hexahydrate $\left(\mathrm{Ni}\left(\mathrm{NO}_{3}\right)_{2} 6 \mathrm{H}_{2} \mathrm{O}\right)$ as the organometallic precursor, on the (101)-facet of the oriented $\mathrm{TiO}_{2}$ nanoparticles. In this way, heterostructure $\mathrm{NiO} /(101)$-anatase- $\mathrm{TiO}_{2}$ nanoparticles were synthesized, characterized by good dispersion of $\mathrm{NiO}$. A NiO loading equal to $0.25 \mathrm{wt} \%$ into the composites exhibited the best photocatalytic activity, which was much higher than that of the pure $\mathrm{TiO}_{2}$ photocatalyst. Moreover, it was proved that no changes occurred in the textural and morphological properties of the employed anatase- $\mathrm{TiO}_{2}$ nanoparticles after the supercritical deposition of $\mathrm{NiO}$ loadings.

Aiming at the production of high-performance nanocomposites, Sun et al. [64] dispersed the coupling system $\mathrm{ZnO} / \mathrm{NiO}$, in the form of nanoparticles, on ordered mesoporous alumina (OMA). The OMA supported $-\mathrm{ZnO} / \mathrm{NiO}$ showed a higher photocatalytic activity for Congo Red decolorization under simulated sunlight irradiation not only with respect to $\mathrm{ZnO} / \mathrm{OMA}$ and $\mathrm{NiO} / \mathrm{OMA}$ composites, but also compared to OMA/ZnO/NiO composites synthesized by the conventional incipient wetness impregnation. These results revealed the potential of the supercritical deposition route to achieve an excellent dispersion of the metallic compounds on the selected support.

In Table 1, a summary of the studies focused on the production of composites by the supercritical deposition for photocatalytic applications is shown. 


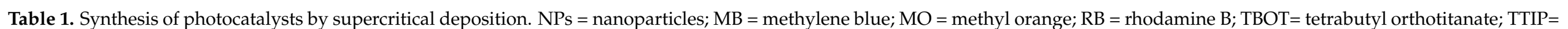

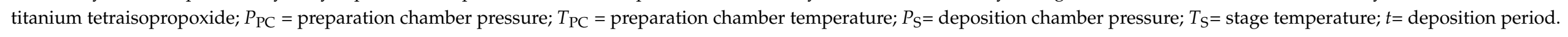

\begin{tabular}{|c|c|c|c|c|c|c|}
\hline $\begin{array}{l}\text { Metal Organic } \\
\text { Precursor }\end{array}$ & Metal Oxide & $\begin{array}{c}\text { Operating } \\
\text { Conditions }\end{array}$ & Mean NPs Diameter & $\begin{array}{l}\text { Photocatalytic } \\
\text { Application }\end{array}$ & Results & Ref. \\
\hline TTIP & $\mathrm{TiO}_{2}$ & $\begin{array}{c}P_{\mathrm{PC}}=11 \mathrm{MPa} ; \\
T_{\mathrm{PC}}=40{ }^{\circ} \mathrm{C} ; \\
P_{\mathrm{S}}=9 \mathrm{MPa} ; \\
T_{\mathrm{S}}=100-180{ }^{\circ} \mathrm{C} ; \\
t=30 \mathrm{~min}\end{array}$ & $2.7 \mathrm{~nm}$ & MB degradation & $\begin{array}{c}40 \% \text { of MB removal after } \\
240 \mathrm{~min}\end{array}$ & [61] \\
\hline $\mathrm{Ti}\left(\mathrm{OC}\left(\mathrm{CH}_{3}\right)_{3}\right)_{4}$ & $\mathrm{TiO}_{2} / \mathrm{SBA}-15$ & - & $2.6-15.3 \mathrm{~nm}$ & $\begin{array}{c}\mathrm{MB}, \mathrm{MO}, \mathrm{RB} \text {, and phenol } \\
\text { degradation }\end{array}$ & $\begin{array}{l}\text { The highest degradation } \\
\text { efficiency with a } \mathrm{TiO}_{2} \\
\text { loading of } 15 \mathrm{wt} \% \text { and a } \\
\text { calcination temperature } \\
\text { of } 400^{\circ} \mathrm{C}\end{array}$ & [62] \\
\hline $\mathrm{Ni}\left(\mathrm{NO}_{3}\right)_{2} \cdot 6 \mathrm{H}_{2} \mathrm{O}$ & $\mathrm{NiO}$ & $\begin{array}{c}P_{\mathrm{PC}}=5 \mathrm{MPa} ; \\
P_{\mathrm{S}}=22 \mathrm{MPa} ; \\
T_{\mathrm{S}}=200^{\circ} \mathrm{C} ; t=30 \mathrm{~min}\end{array}$ & $7 \mathrm{~nm}$ & $\begin{array}{l}\text { MB or MO } \\
\text { Degradation }\end{array}$ & $\begin{array}{l}0.25 \mathrm{wt} \% \mathrm{NiO}-\mathrm{TiO}_{2} \\
\text { showed the highest } \\
\text { efficiency for both } \mathrm{MB} \\
\text { and } \mathrm{MO} \text { degradation }\end{array}$ & [63] \\
\hline $\begin{array}{c}\mathrm{Zn}\left(\mathrm{NO}_{3}\right)_{2} \cdot 6 \mathrm{H}_{2} \mathrm{O} / \\
\mathrm{Ni}\left(\mathrm{NO}_{3}\right)_{2} \cdot 6 \mathrm{H}_{2} \mathrm{O}\end{array}$ & $\mathrm{ZnO} / \mathrm{NiO}$ & $\begin{array}{c}P_{\mathrm{S}}=20 \mathrm{MPa} \\
T_{\mathrm{S}}=50^{\circ} \mathrm{C} ; t=4 \mathrm{~h}\end{array}$ & $21 \mathrm{~nm}$ & $\begin{array}{l}\text { Congo Red } \\
\text { Degradation }\end{array}$ & $\begin{array}{l}\text { About } 97 \% \text { of dye } \\
\text { removal after } 240 \text { min; } \\
\text { superior performance of } \\
\text { catalysts prepared by } \\
\text { supercritical deposition } \\
\text { than those of commercial } \\
\mathrm{TiO}_{2} \text { and of composites } \\
\text { prepared via incipient } \\
\text { wetness impregnation }\end{array}$ & [64] \\
\hline ТВOT & $\mathrm{TiO}_{2}$ & $P_{\mathrm{S}}=20 \mathrm{MPa}$ & - & MB degradation & $\begin{array}{c}\text { Complete } \mathrm{MB} \\
\text { discoloration after } 80 \\
\text { min with } \mathrm{scCO}_{2-} \\
\text { prepared catalyst; a } \\
\text { superior efficiency than } \\
\text { that of commercial } \mathrm{TiO}_{2}\end{array}$ & [65] \\
\hline
\end{tabular}




\section{Supercritical Antisolvent Precipitation of Photocatalytic Nanoparticles}

Up to now, the Supercritical AntiSolvent (SAS) precipitation was widely used to produce nanoparticles of different materials, including metal-based compounds to produce catalysts [66-69] and photocatalysts [42-46] with very high activity and selectivity performance for various reactions.

The SAS process is based on some fundamental prerequisites. Specifically, the $\mathrm{scCO}_{2}$ plays the role of the antisolvent with respect to the solute to be precipitated, whereas it has to be completely miscible with the selected liquid solvent. On the other hand, the solute to be nanonized has to be soluble in the liquid solvent and insoluble in the binary mixture solvent/antisolvent formed in the precipitation chamber during the process. In addition to the fast diffusion of $\mathrm{scCO}_{2}$ into the liquid solvent, the precipitation is thus caused by the supersaturation of the solute. Organometallic precursors of the desired oxides are generally dissolved in liquid solvents to prepare photocatalysts. Briefly, the liquid solution consisting in the solvent and the precursor is injected into the precipitator filled with the $\mathrm{scCO}_{2}$ at the selected temperature and pressure, leading to the attainment of nanoparticles. Then, the as-prepared precursor particles have to be usually calcined at high temperatures to produce the final oxide photocatalyst. Isopropanol, dimethylsulfoxide (DMSO), ethanol and methanol are usually selected as the proper solvents for the precipitation of photocatalyst precursors [42-46].

A typical sketch of a generic SAS process is shown in Figure 2.

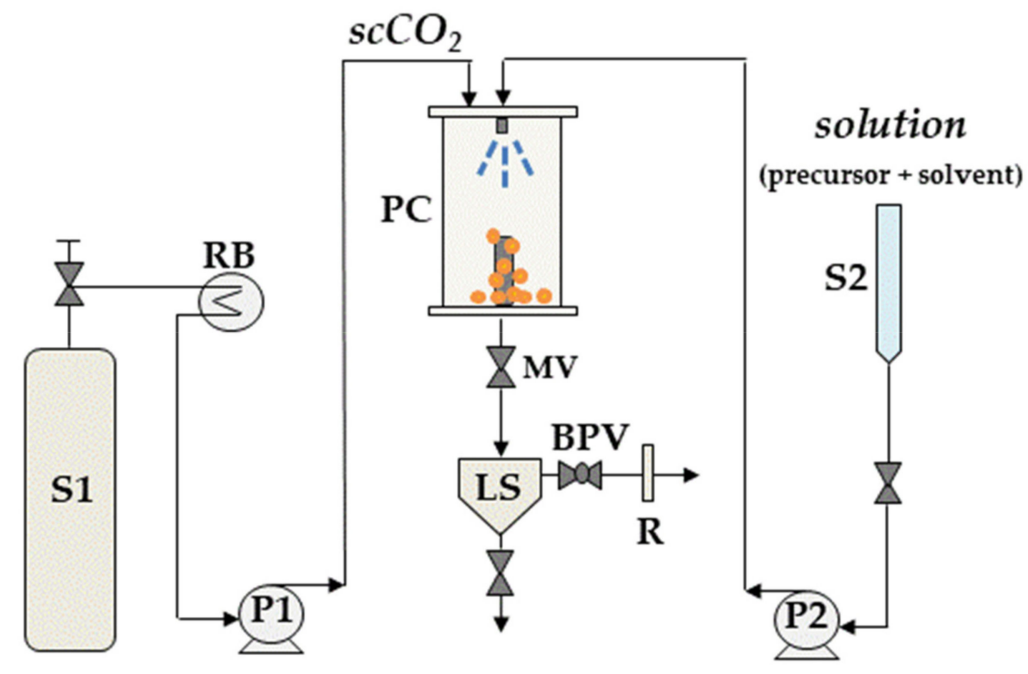

Figure 2. A schematic representation of a generic SAS process. P1, P2: pumps; $\mathrm{S} 1: \mathrm{CO}_{2}$ supply; S2: liquid solution supply; RB: refrigerating bath; PC: precipitation chamber; LS: liquid separator; MV: micrometric valve; BPV: back-pressure valve; R: rotameter.

To date, the SAS technique was mainly employed to produce $\mathrm{TiO}_{2}$ nanoparticles, starting from titanium tetraisopropoxide as precursor [42-44]. Da Silva et al. [43] highlighted that SAS precipitation allows to produce photocatalyst nanoparticles with very high specific surface areas, up to $515 \mathrm{~m}^{2} / \mathrm{g}$ in the specific case of $\mathrm{TiO}_{2}$ nanoparticles prepared by the authors. Moreover, there was a correlation between the photocatalytic activity of $\mathrm{TiO}_{2}$ and its phase composition as well as because of synergism phenomena between different titania phases. In particular, the anatase-rutile ratio strongly affected the photodegradation of methylene blue and methyl orange: for this purpose, the sample composed of $7 \%$ rutile and $93 \%$ anatase emerged as the best one. $\mathrm{SAS} \mathrm{TiO}_{2}$ samples were also superior compare to the commercial photocatalyst known as $\mathrm{P} 25$, which is a widely used $\mathrm{TiO}_{2}$ consisting of anatase and rutile phases. Similarly, Marin et al. [44] prepared $\mathrm{TiO}_{2}$ with a tailored anatase/rutile composition via SAS process, but the SAS-precipitated $\mathrm{TiO}_{2}$ was found to have a comparable activity with commercial $\mathrm{TiO}_{2}$ one for the photocatalytic splitting of water for the hydrogen production. 
In another study [42], SAS-prepared nanocrystalline $\mathrm{TiO}_{2}$ revealed to be effective also in the photodegradation of a dye, namely Reactive Red 180 (RR 180), in water solutions, mainly due to the small particle size, the high surface area (surface area of $63.2 \mathrm{~m}^{2} / \mathrm{g}$ ) and weak agglomeration of the produced powders.

However, generally speaking, the use of $\mathrm{TiO}_{2}$-based photocatalysts is limited by some critical issues, such as the deactivation caused by ions scavengers present in the solution to be treated and low degradation kinetics in solutions with high concentrations of the contaminant to be removed [70]. The superior photocatalytic activity of $\mathrm{ZnO}$ compared to $\mathrm{TiO}_{2}$ is well documented $[24,71,72]$.

Recently, undoped $\mathrm{ZnO}$ and $\mathrm{ZnO}$ doped with Europium $(\mathrm{Eu})$ were also synthesized via the SAS process [45,46]. Specifically, in the studies of Franco et al. [45,46], undoped $\mathrm{ZnO}$ nanoparticles precipitated by SAS were found to be effective in the photocatalytic degradation of both Crystal Violet dye and Eriochrome Black-T Azo dye, even to a greater extent than a $\mathrm{TiO}_{2}$ photocatalyst, in addition to $\mathrm{ZnO}$ prepared using traditional methods. This outcome was assured by the regular nanometric shape, the low particle size and a high exposed surface area of SAS-prepared $\mathrm{ZnO}$. The authors also highlighted the importance of carefully selecting the proper conditions for the thermal treatment of the SAS-prepared precursor to preserve the nanoparticle morphology and size even in the final metal-oxide photocatalyst. Specifically, a calcination temperature equal to $500{ }^{\circ} \mathrm{C}$ (temperature range investigated: $300-600{ }^{\circ} \mathrm{C}$ ) in addition to a slow heating rate equal $2{ }^{\circ} \mathrm{C} \times \mathrm{min}^{-1}$, for 2 $\mathrm{h}$ in air, was revealed to be the best choice to avoid sintering phenomena. In addition, spectroscopic studies proved that organic impurities, which are present in $\mathrm{ZnO}$ obtained from unprocessed $\mathrm{ZnAc}$, completely disappeared after the supercritical processing in the SAS powders. This outcome could further explain the superior photocatalytic performance of SAS-prepared powders.

Aiming to increase the photocatalytic performance of SAS ZnO, a novel simultaneous precipitation of zinc acetate $(\mathrm{ZnAc})$ and europium acetate (EuAc) via SAS process was also proposed by the authors to obtain Eu-doped $\mathrm{ZnO}$ [46]. Indeed, SAS Eu-doped ZnO ensured the highest photocatalytic efficiency in terms of discoloration and mineralization of the Eriochrome Black-T Azo dye. As a future prospect, it could be interesting to investigate the simultaneous precipitation of multiple metal precursors to produce doped-photocatalysts.

Two illustrative images obtained by Field Emission Scanning Electron Microscopy (FESEM) are shown in Figure 3a,b, which show SAS Eu-ZnAc nanoparticles and SAS Eu-doped ZnO photocatalyst, respectively, obtained after the calcination of SAS Eu-ZnAc.

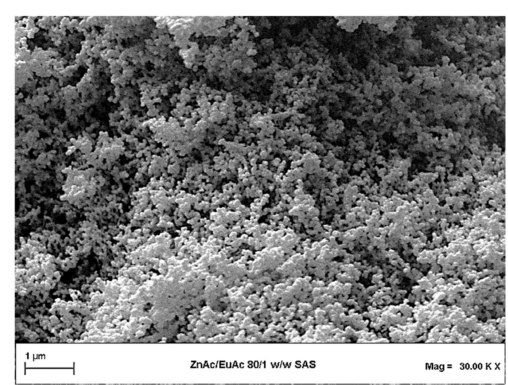

(a)

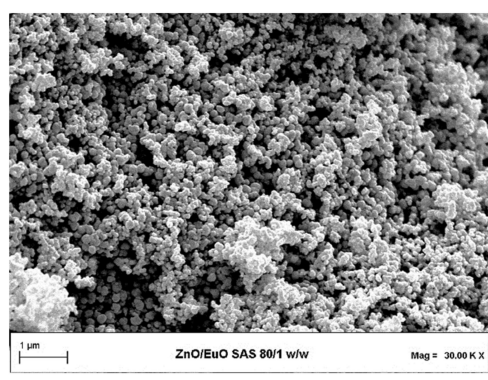

(b)

Figure 3. FESEM images of SAS nanoparticles of (a) Eu-ZnAc before thermal calcination and (b) Eu$\mathrm{ZnO}$ after calcination step.

Table 2 shows a summary of the studies focused on the application of the SAS precipitation to prepare nanoparticulate photocatalysts. 


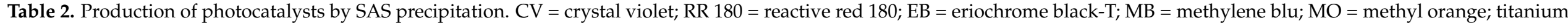
tetraisopropoxide (TTIP); $P=$ operating pressure; $T=$ operating temperature.

\begin{tabular}{|c|c|c|c|c|c|c|c|}
\hline $\begin{array}{l}\text { Metal Organic } \\
\text { Precursor }\end{array}$ & $\begin{array}{l}\text { Metal } \\
\text { Oxide }\end{array}$ & $\begin{array}{l}\text { Operating } \\
\text { Conditions }\end{array}$ & Mean Crystallite Size & $\begin{array}{l}\text { Photocatalytic } \\
\text { Application }\end{array}$ & $\begin{array}{l}\text { Band } \\
\text { Gap }\end{array}$ & Results & Ref. \\
\hline TTIP & $\mathrm{TiO}_{2}$ & $\begin{array}{l}P=10-15 \mathrm{MPa} ; \\
T=50-150{ }^{\circ} \mathrm{C}\end{array}$ & $13 \mathrm{~nm}$ & RR 180 degradation & - & $\begin{array}{c}98 \% \text { of dye removal after } 45 \\
\text { min with } \mathrm{TiO}_{2} \text { prepared at } \\
15 \mathrm{MPa} / 150{ }^{\circ} \mathrm{C}\end{array}$ & [42] \\
\hline TTIP & $\mathrm{TiO}_{2}$ & $\begin{array}{c}P=25 \mathrm{MPa} \\
T=60^{\circ} \mathrm{C}\end{array}$ & $27 \mathrm{~nm}$ & $\begin{array}{l}\text { MB and MO } \\
\text { degradation }\end{array}$ & $3.22 \mathrm{eV}$ & $\begin{array}{l}\text { The highest photodegradation } \\
\text { with } \mathrm{TiO}_{2} \text { consisted of } 7 \mathrm{wt} \% \\
\text { of rutile and } 93 \mathrm{wt} \% \text { of } \\
\text { anatase phase }(98 \% \\
\text { discoloration in } 90 \mathrm{~min})\end{array}$ & [43] \\
\hline $\mathrm{Zn}\left(\mathrm{CH}_{3} \mathrm{COO}\right)_{2}$ & $\mathrm{ZnO}$ & $\begin{array}{c}P=15 \mathrm{MPa} ; \\
T=40^{\circ} \mathrm{C}\end{array}$ & $18 \mathrm{~nm}$ & $\mathrm{CV}$ degradation & $3.10 \mathrm{eV}$ & $\begin{array}{c}500{ }^{\circ} \mathrm{C} \text { as optimum calcination } \\
\text { temperature to preserve the } \\
\text { nanoparticle morphology; } \\
\text { complete } \mathrm{CV} \text { decolorization in } \\
60 \mathrm{~min}\end{array}$ & [45] \\
\hline $\begin{array}{c}\mathrm{Eu}\left(\mathrm{CH}_{3} \mathrm{COO}\right)_{3} \cdot \mathrm{H}_{2} \mathrm{O} \\
\mathrm{Zn}\left(\mathrm{CH}_{3} \mathrm{COO}\right)_{2}\end{array}$ & $\mathrm{Eu}-\mathrm{ZnO}$ & $\begin{array}{c}P=15 \mathrm{MPa} \\
T=40^{\circ} \mathrm{C}\end{array}$ & $15 \mathrm{~nm}$ & EB degradation & $3.22 \mathrm{eV}$ & $\begin{array}{l}\text { Superior catalytic } \\
\text { performance of SAS-prepared } \\
\text { catalysts compared to those of } \\
\text { commercial/traditional } \\
\text { catalysts; complete } \\
\text { discoloration after } 240 \mathrm{~min}\end{array}$ & [46] \\
\hline
\end{tabular}




\section{Sol-Gel Reactions}

Sol-gel reactions in $\mathrm{scCO}_{2}$ have been frequently used for the synthesis of metal/silicon oxides with different geometries on a nanometer scale [73]. In sol-gel processes, the sol is a colloidal suspension of nanometer-sized solid particles in a liquid phase; the gel is formed when the particles bond together forming a three-dimensional network. The use of $\mathrm{scCO}_{2}$ as the reaction media involves many advantages and has been used starting from 1996, when Tadros et al. [74], for the first time, synthesized anatase $\mathrm{TiO}_{2}$ microparticles (mean diameter 0.1-2.0 $\mu \mathrm{m}$ ) using TTIP, an aqueous solution of a surfactant and $\mathrm{scCO}_{2}$. The pressure was fixed at $9.9 \mathrm{MPa}$, the temperature at $50{ }^{\circ} \mathrm{C}$ and the reaction time at $4 \mathrm{~h}$. Subsequently, Reverchon et al. [75] hydrolyzed TTIP in $\mathrm{scCO}_{2}$ to obtain $\mathrm{Ti}(\mathrm{OH})_{4}$ nanoparticles with a mean particle size in the range $90-130 \mathrm{~nm}$. The operating pressure ranged from 8 to $14 \mathrm{MPa}$, whereas the operating temperature ranged from 40 to $60^{\circ} \mathrm{C}$.

Jensen et al. [76] produced nanosized metal oxides through a supercritical seed enhanced crystallization, a modified sol-gel process in which $\mathrm{scCO}_{2}$ is the solvent and different seeding materials can be used. The process was developed at a pressure of $10 \mathrm{MPa}$, a temperature of $100{ }^{\circ} \mathrm{C}$ and considering a process time equal to $4 \mathrm{~h}$. Depending on the seeding material, anatase $\mathrm{TiO}_{2}$ powder with a mean crystal size in the range $6.2-9.3 \mathrm{~nm}$ were obtained. The nanoparticles were used in a subsequent paper [77] to prepare titania nanocrystalline films through a modified sol-gel method. The photocatalytic activity of the films was determined under UV irradiation using stearic acid as a model compound.

Camarillo et al. [78] obtained titania nanofibers (undoped and doped with $\mathrm{Cu}$ ) through a synthesis in $\mathrm{scCO}_{2}$ that was used for the photocatalytic reduction of carbon dioxide with water vapor. The nanofibers were produced using TTIP as precursor of Ti, Copper (II) acetylacetonate as precursor of $\mathrm{Cu}$, and acetic acid as polymerizing agent. Carbon dioxide is pumped into the reactor that contained the previous materials up to the operating pressure $(22-24 \mathrm{MPa})$ and temperature $\left(40-80^{\circ} \mathrm{C}\right)$. During the first three hours of the reaction the mixture is kept under stirring and, subsequently, the reaction is aged for $24 \mathrm{~h}$ under the same pressure and temperature conditions in the absence of stirring. The photocatalytic reduction of $\mathrm{CO}_{2}$ was conducted using the catalyst, obtaining methane and carbon monoxide as the only reaction products.

\section{Sol-Gel Reactions and Supercritical Drying to Obtain Porous Structures}

In some papers, after the sol-gel reaction, a supercritical drying is assessed (Figure 4), obtaining aerogels instead of xerogels since the last ones can suffer from severe shrinkage and loss of microstructure when dried by conventional evaporation.

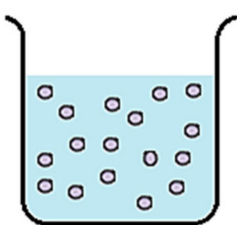

Sol

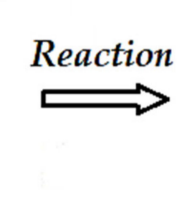

(1)

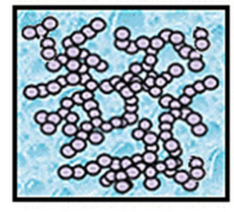

Gel
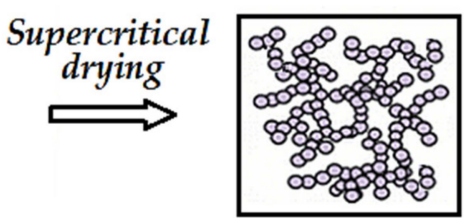

Aerogel

Figure 4. A sketch of sol-gel and supercritical drying stages.

Up to now, $\mathrm{TiO}_{2}$-based photocatalysts have been generally prepared by supercritical drying, mostly in form of aerogels [51,79-83]; however, other novel structures have also been proposed; e.g., nanowires [84], thin films [85], pillared clays [86] or beads [87].

Mumin et al. [84] synthesized anatase $\mathrm{TiO}_{2}$ nanowires through a sol-gel process in $\mathrm{scCO}_{2}$; the precursor of the oxide was TTIP, which was dissolved in acetic acid and put in contact with $\mathrm{scCO}_{2}$ at $41.4 \mathrm{MPa}$ and $60{ }^{\circ} \mathrm{C}$ for $24 \mathrm{~h}$ under stirring and 5 days of aging (to complete the reaction). Then, a supercritical drying step was performed. The photocatalyst was, then, prepared by functionalizing $\mathrm{TiO}_{2}$ nanowires and linking covalently semiconductor quantum dots to the titania surface. The photocatalytic activities of the prepared catalysts have been evaluated under ultraviolet and visible light solar 
irradiation for the photodegradation of methylene blue (MB). In particular, among various proposed and tested samples, the best performance in terms of photodegradation of $\mathrm{MB}$ dye (approximately equal to $88 \%$ ) were exhibited by the nanocomposites consisting in core-shell CdS-ZnS quantum dots linked with $\mathrm{TiO}_{2}$ nanowires. A remarkable aspect is the stability of this nanocomposite system over time; indeed, after three cycling tests, the loss in terms of photocatalytic activity was significantly reduced up to a value of about $10 \%$. On the other hand, for the $\mathrm{MB}$ photodecomposition, $\mathrm{Li}$ et al. [49] proposed $\mathrm{TiO}_{2}-\mathrm{WO}_{3}-\mathrm{Fe}^{3+}$ aerogels prepared using milder conditions in the supercritical drying phase in terms of pressure, temperature and process time (as observable in Table 3), compared to those employed in the study of Mumin et al. [84]. This aspect can be advantageous from both an economic and production time point of view for the long-term industrial preparation of photocatalysts.

Aiming at improving the photocatalytic activity of catalysts, especially those based on $\mathrm{TiO}_{2}$, different approaches have been attempted, including the dispersion of an active species onto the support surface (in general, a noble metal such as $\mathrm{Au}$ [87] and $\mathrm{Pt}$ [88]), as well as the photocatalyst doping [89,90]. In particular, the doping of $\mathrm{TiO}_{2}$ is a promising route to overcome the main issues associated to its use in photocatalysis, including the wide band gap (3-3.2 eV) that requires ultraviolet irradiation for its photocatalytic activation, resulting in a very low energy efficiency under solar light, whose use is still today the main challenge and desired goal. Specifically, $\mathrm{TiO}_{2}$ was doped with both non-metal elements, such as nitrogen [89,91], and transition metal ions, such as Fe(III) [90], involving a final step of supercritical drying to remove the liquid solvent employed, while preserving the native porous structure of the aerogels. In addition to the doping, the use of bimetallic materials is also a valid route to improve the photocatalyst features and performance, as proven in the study of Lucky and Charpentier [91]. Specifically, the authors prepared N-doped $\mathrm{ZrO}_{2} / \mathrm{TiO}_{2}$ nanomaterials, observing that a small and proper amount of nitrogen and zirconia led to an increase in the specific surface area and inhibited the crystals' growth, thus assuring a low degree of crystallinity in the samples. As a result, all the synthesized $\mathrm{N}$-doped $\mathrm{ZrO}_{2} / \mathrm{TiO}_{2}$ samples exhibited a higher activity in photodegradation of methylene blue compared to commercial $\mathrm{P} 25 \mathrm{TiO}_{2}$.

Recently, a biopolymer-templating methodology has also been proposed in some papers [31,87]. Natural alginate is the most selected material as a templating agent for the preparation of metal oxide structures, since it allows to achieve very small particle size and/or very high specific surface area. This result is due to the fact that the transition metals are contained in the alginate once dried in the presence of supercritical $\mathrm{CO}_{2}$.

To date, $\mathrm{TiO}_{2}-\mathrm{SiO}_{2}$ composites involving supercritical drying and/or sol-gel reactions in $\mathrm{scCO}_{2}$ have also been widely proposed for various photocatalytic applications, including water splitting, degradation of benzene, phenol and methanol, oxidation of volatile organic compounds (VOCs) or trichloroethylene [50,83,86,92-94]. In the studies of Cao [93,94], mesoporous titania-silica aerogels with an open-pore structure readily accessible to the reactant molecules have been obtained using $\mathrm{scCO}_{2}$; consequently, a great contact between the reactants and $\mathrm{TiO}_{2}-\mathrm{SiO}_{2}$ led to a high conversion. Specifically, the nanometric crystals of anatase $\mathrm{TiO}_{2}$ (i.e., Ti-O-Ti sites) were well-dispersed and well-anchored within/to the amorphous aerogel network (i.e., $\mathrm{Si}-\mathrm{O}-\mathrm{Ti}$ and $\mathrm{Si}-\mathrm{O}-\mathrm{Si}$ bonds). Furthermore, under similar reaction conditions, catalysts based on commercial $\mathrm{TiO}_{2}$ exhibited lower activity performance than titania-silica aerogels by supercritical ethanol drying.

The studies focused on the application of the sol-gel reaction and the supercritical drying in the photocatalytic field are summarized in Table 3. 


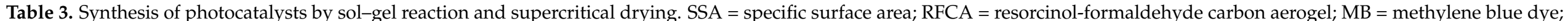

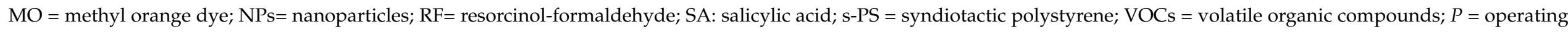
pressure; $T=$ operating temperature; $t=$ drying time.

\begin{tabular}{|c|c|c|c|c|c|c|}
\hline Photocatalyst & $\begin{array}{l}\text { Drying } \\
\text { Conditions }\end{array}$ & $\begin{array}{l}\text { Photocatalytic } \\
\text { Application }\end{array}$ & $\begin{array}{l}\text { Band Gap } \\
\quad(e V)\end{array}$ & $\begin{array}{c}\text { SSA } \\
\left(\mathrm{m}^{2} / \mathrm{g}\right)\end{array}$ & Results & Ref. \\
\hline $\mathrm{TiO}_{2}$ aerogel & - & SA degradation & - & 600 & About $98 \%$ of SA degradation in $900 \mathrm{~min}$ & [51] \\
\hline $\mathrm{TiO}_{2}$ aerogel & $\begin{array}{c}P=8 \mathrm{MPa} \\
T=40^{\circ} \mathrm{C} ; t=6 \mathrm{~h}\end{array}$ & $\begin{array}{l}\text { Phenol } \\
\text { degradation }\end{array}$ & 3.03 & $464^{\mathrm{a}} ; 100^{\mathrm{b}}$ & $\begin{array}{l}\text { Optimum calcination temperature of } 650 \\
{ }^{\circ} \mathrm{C} \text { for the best photocatalytic } \\
\text { performance }(92 \% \text { degradation yield); } \\
\text { superior performance of } \mathrm{scCO}_{2^{-}} \\
\text {prepared samples than that of } \\
\text { commercial } \mathrm{TiO}_{2}\end{array}$ & [80] \\
\hline $\mathrm{TiO}_{2}$ aerogel & $\begin{array}{c}P=8 \mathrm{MPa} \\
T=37^{\circ} \mathrm{C} ; t=4 \mathrm{~h}\end{array}$ & $\begin{array}{l}\text { Methanol assisted water } \\
\text { splitting }\end{array}$ & 3.25 & $600^{\mathrm{a}} ; 97^{\mathrm{b}}$ & $\begin{array}{l}\text { Higher activity of } \mathrm{scCO}_{2} \text { - prepared } \\
\text { samples than that of commercial } \mathrm{TiO}_{2}\end{array}$ & [79] \\
\hline $\mathrm{TiO}_{2}$ aerogel & $\begin{array}{l}P=10 \mathrm{MPa} \\
T=50^{\circ} \mathrm{C}\end{array}$ & $\begin{array}{c}\text { Phenol } \\
\text { degradation }\end{array}$ & - & $112^{\mathrm{b}}$ & $\begin{array}{c}\mathrm{scCO}_{2} \text { - prepared aerogel } 3 \text { times more } \\
\text { active than commercial } \mathrm{TiO}_{2}\end{array}$ & [81] \\
\hline $\mathrm{TiO}_{2}$ aerogel & $\begin{array}{l}P=8.27 \mathrm{MPa} \\
T=35^{\circ} \mathrm{C}\end{array}$ & Water splitting & - & $84.5^{\mathrm{b}}$ & $\begin{array}{l}\mathrm{H}_{2} \text { evolution rate } 9.6 \text { times higher with } \\
\mathrm{scCO}_{2} \text { - prepared aerogel compared to } \\
\text { that of commercial } \mathrm{TiO}_{2}\end{array}$ & [82] \\
\hline $\mathrm{TiO}_{2}$ nanowires & $\begin{array}{c}P=41.4 \mathrm{MPa} \\
T=60^{\circ} \mathrm{C} ; t=24 \mathrm{~h}\end{array}$ & MB degradation & 2.5 & - & $\begin{array}{l}\text { MB degradation efficiency equal to } 88 \% \text {; } \\
\text { higher activity of } \mathrm{scCO}_{2} \text { - prepared } \\
\text { samples than that of commercial one }\end{array}$ & [84] \\
\hline $\mathrm{TiO}_{2}$ pillared clays & $\begin{array}{c}P=20 \mathrm{MPa} ; \\
T=50^{\circ} \mathrm{C} ; t=3 \mathrm{~h}\end{array}$ & Phenol degradation & - & $254^{\mathrm{a}}$ & Total degradation in less than $125 \mathrm{~min}$ & [86] \\
\hline $\mathrm{N}$-doped $\mathrm{TiO}_{2}$ aerogel & $\begin{array}{c}P=20 \mathrm{MPa} \\
T=40^{\circ} \mathrm{C} ; t=4 \mathrm{~h}\end{array}$ & Phenol degradation & 2.5 & $280^{\mathrm{a}}$ & $45 \%$ of degradation after $180 \mathrm{~min}$ & [89] \\
\hline $\begin{array}{l}\mathrm{Fe}(\mathrm{III}) \text {-doped } \mathrm{TiO}_{2} \\
\text { aerogel }\end{array}$ & - & SA degradation & - & $151^{\mathrm{b}}$ & $\begin{array}{c}\mathrm{TiO}_{2} \text { - based aerogel with } 1.8 \text { at.\% Fe(III) } \\
\text { showed an apparent rate constant of } \mathrm{SA} \\
\text { degradation } 6 \text { times higher than } \\
\text { commercial } \mathrm{TiO}_{2}\end{array}$ & [90] \\
\hline $\mathrm{TiO}_{2}-\mathrm{Pt}$ aerogel & $\begin{aligned} P & =9.5 \mathrm{MPa} \\
T & =40{ }^{\circ} \mathrm{C}\end{aligned}$ & Ethanol reforming & 2.91-3.14 & $600^{\mathrm{a}} ; 162^{\mathrm{b}}$ & $\begin{array}{l}\text { The highest } \mathrm{H}_{2} \text { production rate }(7.2 \\
\left.\mathrm{mmol}_{\mathrm{H} 2} \mathrm{~h}^{-1} \mathrm{~g}^{-1}\right) \text { with } 1 \% \mathrm{Pt} \text { and the } \\
\text { smallest particles size }\end{array}$ & [88] \\
\hline $\mathrm{TiO}_{2}-\mathrm{SiO}_{2}$ aerogel & - & Water splitting & 3.42 & $715^{\mathrm{a}}$ & $\begin{array}{l}\mathrm{H}_{2} \text { production } \\
\text { in the range } \\
0.73-1.35 \mathrm{mmol} / \mathrm{g}_{\mathrm{TiO} 2}\end{array}$ & [50] \\
\hline
\end{tabular}


Table 3. Cont.

\begin{tabular}{|c|c|c|c|c|c|c|}
\hline Photocatalyst & $\begin{array}{l}\text { Drying } \\
\text { Conditions }\end{array}$ & $\begin{array}{l}\text { Photocatalytic } \\
\text { Application }\end{array}$ & $\begin{array}{l}\text { Band Gap } \\
\quad(e V)\end{array}$ & $\begin{array}{c}\text { SSA } \\
\left(\mathrm{m}^{2} / \mathrm{g}\right)\end{array}$ & Results & Ref. \\
\hline $\mathrm{TiO}_{2}-\mathrm{SiO}_{2}$ aerogel & $\begin{array}{c}P=16 \mathrm{MPa} \\
T=80-2800^{\circ} \mathrm{C} ; t=3 \mathrm{~h}\end{array}$ & $\begin{array}{c}\text { Benzene } \\
\text { decomposition }\end{array}$ & - & $967^{a}$ & $\begin{array}{l}\text { Benzene conversion up to } 90 \% \text { after } 30 \\
\min \end{array}$ & [92] \\
\hline $\mathrm{TiO}_{2}-\mathrm{SiO}_{2}$ aerogel & $\mathrm{T}=50^{\circ} \mathrm{C}$ & $\begin{array}{l}\text { Trichloroethylene } \\
\text { Oxidation }\end{array}$ & & $469^{\mathrm{a}} ; 306^{\mathrm{b}}$ & $\begin{array}{c}\mathrm{TiO}_{2}-\mathrm{SiO}_{2} \text { aerogel prepared by ethanol } \\
\text { supercritical drying showed the highest } \\
\text { conversion (around } 30 \% \text { ), also compared } \\
\text { to that of commercial } \mathrm{TiO}_{2}\end{array}$ & [94] \\
\hline $\begin{array}{c}\mathrm{TiO}_{2} \text { aerogel; } \\
\mathrm{TiO}_{2}-\mathrm{SiO}_{2} \text { aerogel }\end{array}$ & $\begin{aligned} P & =11 \mathrm{MPa} ; \\
T & =60^{\circ} \mathrm{C}\end{aligned}$ & Degradation of methanol & - & $150 ; 635$ & $\begin{array}{l}98 \% \text { conversion, almost double } \\
\text { compared to commercial } \mathrm{TiO}_{2}\end{array}$ & [83] \\
\hline $\mathrm{TiO}_{2}-\mathrm{SiO}_{2}$ pillared clays & $\begin{array}{c}P=20 \mathrm{MPa} \\
T=50^{\circ} \mathrm{C} ; t=3 \mathrm{~h}\end{array}$ & Phenol degradation & - & $400^{\mathrm{a}}$ & $\begin{array}{c}\text { Lower activity of } \mathrm{TiO}_{2}-\mathrm{SiO}_{2} \text { pillared } \\
\text { clays compared to that of } \mathrm{TiO}_{2} \text { pillared } \\
\text { clays }\end{array}$ & [86] \\
\hline $\mathrm{TiO}_{2}-\mathrm{RFCA}$ & - & MO degradation & - & 645 & $\begin{array}{l}\text { More effective photocatalytic activity in } \\
\text { the case of the } \mathrm{TiO}_{2}-\mathrm{RFCA} \text { composites } \\
\text { compared to the single materials }\end{array}$ & [95] \\
\hline $\mathrm{TiO}_{2}-\mathrm{WO}_{3}-\mathrm{Fe}^{3+}$ aerogel & $\begin{array}{c}P=11 \mathrm{MPa} \\
T=42^{\circ} \mathrm{C} ; t=8 \mathrm{~h}\end{array}$ & MB degradation & 2.06 & $379^{\mathrm{a}} ; 154^{\mathrm{b}}$ & $\begin{array}{l}\text { About } 90 \% \text { and } 70 \% \text { of MB degradation } \\
\text { after } 12 \mathrm{~h} \text { under UV or visible light, } \\
\text { respectively }\end{array}$ & [49] \\
\hline $\mathrm{ZnO} / \mathrm{s}-\mathrm{PS}$ & $\begin{array}{c}P=20 \mathrm{MPa} \\
T=40^{\circ} \mathrm{C} ; t=4 \mathrm{~h}\end{array}$ & Phenol degradation & - & $276^{\mathrm{a}}$ & $\begin{array}{l}\text { Phenol removal increased by increasing } \\
\text { the pH of the solution; synergy between } \\
\text { photocatalyst and PS-based support } \\
\text { assured robustness, chemical stability, } \\
\text { easy recovery after treatment, high } \\
\text { removal efficiency and selectivity }\end{array}$ & [96] \\
\hline $\mathrm{Au} / \mathrm{TiO}_{2}$ alginate beads & - & Water splitting & - & $485-275^{a} ; 187-136^{b}$ & $\begin{array}{c}\mathrm{Au} / \mathrm{TiO}_{2} \text { alginate beads are } 8 \text { times } \\
\text { more active under solar light than } \\
\text { commercial } \mathrm{TiO}_{2} \text { with the same } \mathrm{Au} \\
\text { amount }\end{array}$ & [87] \\
\hline
\end{tabular}


Table 3. Cont.

\begin{tabular}{|c|c|c|c|c|c|c|}
\hline Photocatalyst & $\begin{array}{l}\text { Drying } \\
\text { Conditions }\end{array}$ & $\begin{array}{l}\text { Photocatalytic } \\
\text { Application }\end{array}$ & $\begin{array}{l}\text { Band Gap } \\
(\mathrm{eV})\end{array}$ & $\begin{array}{c}\text { SSA } \\
\left(\mathrm{m}^{2} / \mathrm{g}\right)\end{array}$ & Results & Ref. \\
\hline $\begin{array}{c}\mathrm{Au} / \mathrm{CeO}_{2} \mathrm{NPs} \text { dispersed } \\
\text { on alginate aerogel }\end{array}$ & - & Water splitting & - & 102 & $\begin{array}{c}\text { Photocatalytic activity of } \mathrm{Au} / \mathrm{CeO}_{2} \mathrm{NPs} \\
\text { under visible light outperform that of } \\
\text { standard } \mathrm{WO}_{3} \text { even under UV } \\
\text { irradiation. }\end{array}$ & [31] \\
\hline Ti-organic aerogel & - & $\begin{array}{l}\text { Degradation } \\
\text { of various dyes }\end{array}$ & $3.4-3.2$ & $688-350^{\mathrm{b}}$ & $\begin{array}{l}\text { Effective stimuli-response of } \\
\text { Ti-oxo-based materials }\end{array}$ & [97] \\
\hline $\mathrm{N}$-doped $\mathrm{ZrO}_{2} / \mathrm{TiO}_{2}$ & - & MB degradation & - & $56-94$ & 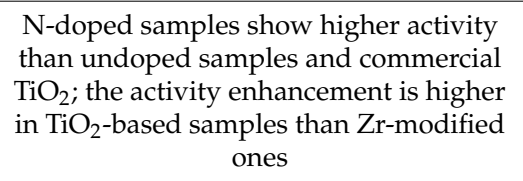 & [91] \\
\hline $\begin{array}{l}\mathrm{TiO}_{2} / \text { RF polymer aerogel; } \\
\mathrm{TiO}_{2} / \text { RF carbon aerogel }\end{array}$ & - & MO degradation & - & $232-870$ & $\begin{array}{c}\mathrm{TiO}_{2} / \mathrm{RF} \text { carbon aerogel more active } \\
\text { than } \mathrm{TiO}_{2} / \mathrm{RF} \text { polymer aerogel in } \mathrm{MO} \\
\text { photodegradation }\end{array}$ & [95] \\
\hline
\end{tabular}

a SSA evaluated before calcination; ${ }^{\mathrm{b}}$ SSA evaluated after calcination. 


\section{Other Applications of Supercritical $\mathrm{CO}_{2}$ in Photocatalysis: From Supercritical Foaming to $\mathrm{ScCO}_{2}$ as a Promising Reaction Medium}

Supercritical $\mathrm{CO}_{2}$ has also been exploited in the photocatalytic field for other multiple purposes.

For example, before the sol-gel reaction, a supercritical pre-treatment has been conducted in some cases, aiming at the production of composite systems such as $\mathrm{TiO}_{2}$-coated carbon surface $[98,99]$ or $\mathrm{TiO}_{2}$-coated zeolite surface [100]. In particular, this preliminary pretreatment consists in the supercritical impregnation of a plugging agent (such as paraffin $[98,100]$ ) into porous carbon or zeolite (i.e., the support for $\mathrm{TiO}_{2}$ ) to form sealed substrates. On the other hand, post-treatments under supercritical conditions can also be performed on photocatalysts. For example, Wang et al. [101] prepared mesostructured $\mathrm{TiO}_{2}$ thin films supported on silicon substrates by spin coating. The supercritical posttreatment of the thin films led to a remarkable improvement in the thermal stability of the mesoporous coatings without affecting the optical transparency or the integrity of samples. Indeed, the unidirectional contraction of the films and the pores collapsing were avoided in the case of the photocatalysts post-treated by $\mathrm{scCO}_{2} \cdot \mathrm{TiO}_{2}$ thin films after supercritical processing also exhibited a very high photoactivity in the degradation of waste organic compounds.

$\mathrm{Up}$ to now, supercritical $\mathrm{CO}_{2}$ has been widely used for the attainment of catalysts characterized by different structures/morphologies. In this context, Zhang et al. [102] exploited the $\mathrm{scCO}_{2}$ to modify Ruthenium-coordinated metal-organic frameworks (MOFs), promoting the formation of a highly mesoporous and microporous structure. The supercritical processing resulted in a high porosity into composites that facilitated the mass transport, an enhanced capability to adsorption visible-light and, consequently, a higher photocatalytic activity for the hydrogen production compared to those of pure MOF and MOF functionalized with Ru. Marković et al. [103] suggested a novel approach to prepare floating photocatalysts for the degradation of textile dyes, namely C.I. Acid Orange 7 (AO7) and C.I. Basic Yellow 28 (BY28). This route consisted in the foaming of poly( $\varepsilon$-caprolactone) (PCL) beads using $\mathrm{scCO}_{2}$, thus promoting the formation of a highly porous structure, subsequently loaded with $\mathrm{TiO}_{2}$ nanoparticles. A sustainable floatability of the photocatalyst based on PCL foams was observed for a long period of time.

Another interesting aspect is the use of $\mathrm{scCO}_{2}$ as a reaction medium [55], for example, in the thermal hydrolysis for the catalyst preparation [104-107]. In this context, Camarillo et al. [104] synthesized a Palladium-doped $\mathrm{TiO}_{2}$ photocatalyst via thermal hydrolysis assisted by supercritical $\mathrm{CO}_{2}$ as reaction medium, using two different $\mathrm{TiO}_{2}$ precursors (i.e., titanium tetraisopropoxide and diisopropoxititanium bis(acetylacetonate)) and palladium acetylacetonate. The main aim was to produce highly efficient photocatalysts for the reduction of $\mathrm{CO}_{2}$ to hydrocarbons, which will be used as more convenient fuels from both environmental and economic points of view, finally passing from a laboratory process to a commercial scale. The as-prepared photocatalysts showed improved properties, mainly higher surface area and absorbance of visible light, in addition to more efficient production of methane (up to 22 times), compared to those of commercial $\mathrm{TiO}_{2}$. Similar benefits in the photocatalytic reduction of $\mathrm{CO}_{2}$, employing $\mathrm{TiO}_{2}$-based catalysts prepared by $\mathrm{scCO}_{2}$, were also highlighted in other papers $[47,106-108]$. The exploit of $\mathrm{scCO}_{2}$ in the photoelectrochemical field has also been recently attempted $[109,110]$. Table 4 reports an overview of other $\mathrm{scCO}_{2}$ applications in photocatalysis. 


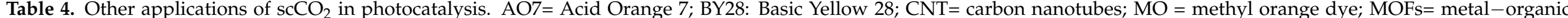
frameworks; $\mathrm{MB}$ = methylene blue dye; $\mathrm{RGO}=$ reduced graphene oxide; $\mathrm{SSA}$ = specific surface area of the photocatalysts.

\begin{tabular}{|c|c|c|c|c|c|}
\hline Photocatalyst & $\mathrm{scCO}_{2}$ Use & $\begin{array}{c}\text { Photocatalytic } \\
\text { Application }\end{array}$ & $\begin{array}{c}\text { SSA } \\
\left(\mathrm{m}^{2} / \mathrm{g}\right)\end{array}$ & Results & Ref. \\
\hline $\begin{array}{c}\mathrm{TiO}_{2} \text {-coated } \\
\text { carbon surface }\end{array}$ & Supercritical pre-treatment before sol-gel reaction & MB degradation & $378-487$ & $\begin{array}{l}\text { Optimal conditions for the fastest MB degradation } \\
\text { rate: } \mathrm{MB} \text { concentration of } 20 \mathrm{mg} / 1 / 1 \mathrm{at} \mathrm{pH} 6 \text {, catalyst } \\
\text { content of } 2.5 \mathrm{~g} / 1\end{array}$ & [98] \\
\hline $\begin{array}{c}\mathrm{TiO}_{2} \text {-coated } \\
\text { carbon surface }\end{array}$ & Supercritical pre-treatment before sol-gel reaction & $\begin{array}{l}\text { Degradation of } \\
\text { acid yellow }\end{array}$ & $325-575$ & $\begin{array}{l}\text { The degradation rate follows a pseudo-first order } \\
\text { kinetics with the acid yellow concentration, it is } \\
\text { proportional to the square root of the light intensity }\end{array}$ & [99] \\
\hline $\begin{array}{c}\mathrm{TiO}_{2} \text {-coated } \\
\text { zeolite surface }\end{array}$ & Supercritical pre-treatment before sol-gel reaction & $\begin{array}{l}\text { Degradation of } \\
\text { Rhodamine B }\end{array}$ & $103-267$ & $\begin{array}{l}\text { Optimal conditions for the fastest degradation rate: } \\
\text { Rhodamine concentration of } 2 \mathrm{mg} / 1 \text { at pH 10, } \\
\text { catalyst content of } 6 \mathrm{~g} / 1\end{array}$ & [100] \\
\hline $\begin{array}{c}\mathrm{TiO}_{2} \text {-film supported } \\
\text { on silicon substrate }\end{array}$ & Supercritical post-treatment & $\begin{array}{c}\text { Decomposition of } \\
\text { stearic acid }\end{array}$ & - & $\begin{array}{l}\text { High photocatalytic efficiency with sc(- } \mathrm{sco}_{2} \text {-reated } \\
\text { films (complete decomposition after } 75 \mathrm{~min} \text { ) }\end{array}$ & [101] \\
\hline Ru-coordinated MOFs & $\begin{array}{l}\text { Modification of } \\
\text { MOFs structure }\end{array}$ & Hydrogen production & 996-1257 & $\begin{array}{l}\mathrm{scCO}_{2} \text {-modified MOFs exhibited a higher activity } \\
\text { than those of the pure MOF and MOF loaded with } \\
\text { Ru particles }\end{array}$ & [102] \\
\hline $\mathrm{TiO}_{2}$-loaded PCL foams & PCL foaming & Removal of textile dyes & - & $\begin{array}{l}\text { Complete discoloration of AO7 and BY28 after } 300 \\
\text { and } 180 \mathrm{~min} \text {, respectively }\end{array}$ & [103] \\
\hline $\begin{array}{l}\mathrm{Au} / \mathrm{ZnO} \text { layered } \\
\text { structure on silk textile }\end{array}$ & $\begin{array}{l}\text { Electroless plating and } \\
\text { cathodic deposition } \\
\text { of metal oxides on silk }\end{array}$ & $\begin{array}{l}\text { Flexible wearable } \\
\text { device }\end{array}$ & - & $\begin{array}{l}\text { Issues related to conventional electroless plating } \\
\text { overcome by sc-Co2: the silk was catalyzed without } \\
\text { defects; ahhesive property between silk and } \\
\text { metalized-layer was enhanced }\end{array}$ & [109] \\
\hline $\mathrm{Ag} / \mathrm{WO}_{3}$ nanosheets & $\begin{array}{c}\text { Supercritical exfoliation } \\
\text { of } \mathrm{WS}_{2} \text { nanosheets }\end{array}$ & $\begin{array}{c}\text { Oxygen evolution } \\
\text { reactions }\end{array}$ & - & $\begin{array}{l}\text { Synergistic photocatalysis effect of } \mathrm{Ag} \text { and } \\
\text { amorphous } \mathrm{WO}_{3}\end{array}$ & [110] \\
\hline Pd-doped $\mathrm{TiO}_{2}$ & $\mathrm{scCO}_{2}$ as reaction medium for thermal hydrolysis & $\begin{array}{l}\text { Reduction of } \mathrm{CO}_{2} \\
\text { to hydrocarbons }\end{array}$ & $71-146$ & $\begin{array}{l}\mathrm{Pd}^{\mathrm{Pd}} \mathrm{Ti} \mathrm{O}_{2} \text { exhibited } \mathrm{CH}_{4} \text { and } \mathrm{CO} \text { production rates up } \\
\text { to } 22 \text { and } 2 \text { times higher than those of commercial } \\
\text { Tiio }\end{array}$ & [104] \\
\hline $\mathrm{TiO}_{2}$ powders & $\mathrm{scCO}_{2}$ as reaction medium for catalyst synthesis & $\begin{array}{c}\text { Reduction of } \mathrm{CO}_{2} \\
\text { to formic acid }\end{array}$ & - & 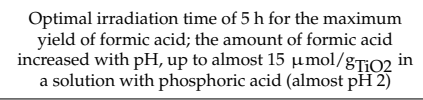 & [47] \\
\hline $\begin{array}{c}\mathrm{CNT} / \mathrm{TiO}_{2} \text { and } \\
\text { CNT/ Cu-dopedTiO }\end{array}$ & $\mathrm{scCO}_{2}$ as reaction medium for thermal hydrolysis & $\begin{array}{l}\text { Reduction of } \mathrm{CO}_{2} \\
\text { to hydrocarbons }\end{array}$ & $150-216$ & $\begin{array}{l}\mathrm{CNT} / \mathrm{TiO}_{2} \text { composites showed } \mathrm{CO} \text { and } \mathrm{CH}_{4} \\
\text { production rates }\left(8.1 \text { and } 1.1 \text {. } \mu \mathrm{mol} \mathrm{g}^{-1} \mathrm{~h}^{-1}\right. \\
\text { respectively) } 4 \text { and } 15 \text { times higher than those of } \\
\text { commercial TiOO }\end{array}$ & [106] \\
\hline $\mathrm{TiO}_{2}$ powders & $\mathrm{scCO}_{2}$ as reaction medium for thermal hydrolysis & $\begin{array}{l}\text { Reduction of } \mathrm{CO}_{2} \\
\text { to hydrocarbons }\end{array}$ & 40-152 & $\begin{array}{l}\mathrm{TiO}_{2} \text { synthesis in supercritical medium resulted in a } \\
\text { significant enhancement in the rate of } \mathrm{CO}_{2} \text { catalytic } \\
\text { conversion }\end{array}$ & [107] \\
\hline $\mathrm{TiO}_{2}$ powders & $\mathrm{scCO}_{2}$ as reaction medium for thermal hydrolysis & MO oxidation & $113-350$ & 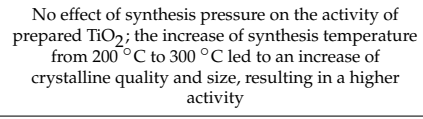 & [105] \\
\hline $\mathrm{RGO} / \mathrm{ZnO}$ & 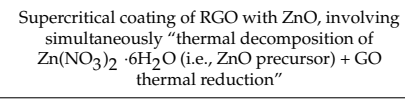 & Hydrogen production & - & $\begin{array}{l}\mathrm{ZnO} / \mathrm{RGO} \text { composite exhibited a } \mathrm{H}_{2} \text { production } \\
\text { activity } 4.5 \text { times higher }(289 \mu \mathrm{mol} / \mathrm{g} \text { ) than that of } \\
\text { pure } \mathrm{ZnO}(61.5 \mu \mathrm{mol} / \mathrm{g}) \text { in } 2 \mathrm{~h}\end{array}$ & [111] \\
\hline $\mathrm{TiO}_{2}$ powders & $\mathrm{scCO}_{2}$ as reaction medium for octanol oxidation & Octanol oxidation & 50 & $\begin{array}{l}\text { Possibility to improve yield and selectivity by } \\
\text { modulating temperature or pressurecaboveve the } \\
\text { critical point, photooxidative degradation rate } \\
\text { increased as scCO } 2 \text { pressure decreased at } 36^{\circ} \mathrm{C}\end{array}$ & [48] \\
\hline
\end{tabular}


An overview about the various applications of $\mathrm{scCO}_{2}$ in photocatalysis and the related advantages is shown in Table 5.

Table 5. A summary about the applications and the advantages of using $\mathrm{scCO}_{2}$ in photocatalysis.

Applications PROS

As a solvent for the deposition of semiconductors/active species on/in the support surface

As a solvent/antisolvent/co-solute in the production of particles-based powders
- Reduction or often complete elimination of the use of toxic organic solvents

- $\quad$ Preserving of porous structure of the supports without collapse

- High mass transfer

- Good and homogeneous dispersion of the metal-based compounds

- Reduction/elimination of the use of toxic organic solvents

- $\quad$ Good control of particles' morphology and size by modulating the operating conditions

- Possibility to obtain very small size due to gas-like and liquid-like properties of $\mathrm{scCO}_{2}$

- Very high surface area

- Total removal of organic solvents from powder

- Total removal of organic solvents

- $\quad$ Porous structure is preserved, without collapse

Production of aerogels

- Very high surface area

- No toxic organic solvents are used

- Possibility to control pores' size by modulating the operating conditions

As a foaming agent

- Very high surface area

- $\quad$ Possibility to perform a one-step process "support foaming + deposition of organometallic precursors"

- $\quad \mathrm{scCO}_{2}$ is not flammable

- $\mathrm{scCO}_{2}$ is easy to recycle on an industrial scale

- $\mathrm{scCO}_{2}$ is less polluting than other solvents/reaction media

- rapid and complete removal of $\mathrm{scCO}_{2}$ by depressurization, avoiding the contamination of products

As a reaction medium

- Improvement in mass transfer

- Possibility to optimize the efficiency/selectivity by tuning the operating conditions and, consequently, the $\mathrm{scCO}_{2}$ properties

- Possibility to simultaneously perform also a supercritical coating/deposition, foaming, etc. 


\section{Conclusions}

The versatility of the supercritical $\mathrm{CO}_{2}$ allows its application in photocatalytic fields for multiple purposes. Among them, the preparation of photocatalysts by $\mathrm{scCO}_{2}$-assisted processes was revealed to be a very promising route to assure high performance for different kinds of reactions. The supercritical techniques are useful to synthesize photocatalysts in various forms, from nanoparticles to aerogels, by preserving the native structure due to the absence of capillary pressure. Moreover, reduced use of toxic and polluting solvents, or even their total elimination, is involved during the supercritical processing, leading to a lower environmental impact involved in the long-term catalyst preparation. The attainment of solvent-free catalysts also avoids the presence of any poisons on their surface, which can cause catalyst deactivation. The photocatalysts prepared by supercritical processes generally exhibit a higher photoactivity compared to that of commercial catalysts. This improved performance is primarily due to a very high surface area of the materials, providing an excellent contact between the reactant molecules and the photocatalyst.

For future perspectives, it is interesting to exploit the use of supercritical technologies in the preparation of doped photocatalysts in all forms, which is still limited to a few studies. Indeed, in addition to the deposition of noble metals onto the support surface, the doping of photocatalysts is a promising route to improve further the catalyst performance. It is also worth investigating the development of novel catalyst structures, for example, using supercritical foaming to produce floating photocatalysts. The main challenge in photocatalysis is still to produce photocatalysts that have to be very active not only under UV irradiation but especially under visible light, also considering an economic point of view. The use of the supercritical $\mathrm{CO}_{2}$ as a reaction medium is also an interesting aspect; it is advisable to attempt to extend it to a wide variety of reactions. For various reasons, the photocatalytic reduction of $\mathrm{CO}_{2}$ involving the use of $\mathrm{scCO}_{2}$ as a reaction medium is very industrially attractive. Indeed, it is possible to re-use the $\mathrm{CO}_{2}$ captured from the industrial emissions as a feedstock for the photochemical production of fuels or reaction intermediates in large-scale plants, combining both environmental and economic benefits.

Author Contributions: Conceptualization, P.F., O.S., V.V. and I.D.M.; methodology, P.F. and O.S.; writing—original draft preparation, P.F.; writing—review and editing, I.D.M.; supervision, V.V. and I.D.M. All authors have read and agreed to the published version of the manuscript.

Funding: This research received no external funding.

Institutional Review Board Statement: Not applicable.

Informed Consent Statement: Not applicable.

Data Availability Statement: Not applicable.

Conflicts of Interest: The authors declare no conflict of interest.

\section{References}

1. Baldino, L.; Cardea, S.; Reverchon, E. Supercritical assisted electrospray: An improved micronization process. Polymers 2019, 11, 244. [CrossRef]

2. Baldino, L.; Cardea, S.; Scognamiglio, M.; Reverchon, E. A new tool to produce alginate-based aerogels for medical applications, by supercritical gel drying. J. Supercrit. Fluids 2019, 146, 152-158. [CrossRef]

3. Campardelli, R.; Trucillo, P.; Reverchon, E. Supercritical assisted process for the efficient production of liposomes containing antibiotics for ocular delivery. J. CO2 Util. 2018, 25, 235-241. [CrossRef]

4. Dos Santos, L.C.; Johner, J.C.F.; Scopel, E.; Pontes, P.V.A.; Ribeiro, A.P.B.; Zabot, G.L.; Batista, E.A.C.; Meireles, M.A.A.; Martínez, J. Integrated supercritical $\mathrm{CO}_{2}$ extraction and fractionation of passion fruit (Passiflora edulis Sims) by-products. J. Supercrit. Fluids 2021, 168. [CrossRef]

5. Pajnik, J.; Lukić, I.; Dikić, J.; Asanin, J.; Gordic, M.; Misic, D.; Zizović, I.; Korzeniowska, M. Application of supercritical solvent impregnation for production of zeolite modified starch-chitosan polymers with antibacterial properties. Molecules 2020, $25,4717$. [CrossRef] [PubMed]

6. Franco, P.; De Marco, I. Eudragit: A novel carrier for controlled drug delivery in supercritical antisolvent coprecipitation. Polymers 2020, 12, 234. [CrossRef] [PubMed] 
7. Tabernero, A.; Cardea, S. Supercritical carbon dioxide techniques for processing microbial exopolysaccharides used in biomedical applications. Mat. Sci. Eng. C 2020, 112. [CrossRef]

8. Wang, C.H.; Hsieh, D.J.; Periasamy, S.; Chuang, C.T.; Tseng, F.W.; Kuo, J.C.; Tarng, Y.W. Regenerative porcine dermal collagen matrix developed by supercritical carbon dioxide extraction technology: Role in accelerated wound healing. Materialia 2020, 9. [CrossRef]

9. Belizón, M.; Fernández-Ponce, M.T.; Casas, L.; Mantell, C.; Martínez De La Ossa-Fernández, E.J. Supercritical impregnation of antioxidant mango polyphenols into a multilayer PET/PP food-grade film. J. CO2 Util. 2018, 25, 56-67. [CrossRef]

10. Franco, P.; Incarnato, L.; De Marco, I. Supercritical CO2 impregnation of $\alpha$-tocopherol into PET/PP films for active packaging applications. J. CO2 Util. 2019, 34, 266-273. [CrossRef]

11. Gong, D.; Jing, X.; Zhao, Y.; Zheng, H.; Zheng, L. One-step supercritical CO2color matching of polyester with dye mixtures. J. CO2 Util. 2021, 44. [CrossRef]

12. Penthala, R.; Heo, G.; Kim, H.; Lee, I.Y.; Ko, E.H.; Son, Y.A. Synthesis of azo and anthraquinone dyes and dyeing of nylon-6,6 in supercritical carbon dioxide. J. CO2 Util. 2020, 38, 49-58. [CrossRef]

13. Costa, J.M.; Almeida Neto, A.F.D. Nanocatalysts deposition assisted by supercritical carbon dioxide technology: A review. Synth. Met. 2021, 271. [CrossRef]

14. Elmanovich, I.V.; Stakhanov, A.I.; Zefirov, V.V.; Pavlov, A.A.; Lokshin, B.V.; Gallyamov, M.O. Thermal oxidation of polypropylene catalyzed by manganese oxide aerogel in oxygen-enriched supercritical carbon dioxide. J. Supercrit. Fluids 2020, 158. [CrossRef]

15. Papoulis, D. Halloysite based nanocomposites and photocatalysis: A Review. Appl. Clay Sci. 2019, 168, 164-174. [CrossRef]

16. Ibhadon, A.O.; Fitzpatrick, P. Heterogeneous Photocatalysis: Recent Advances and Applications. Catalysts 2013, 3, 189-218. [CrossRef]

17. Kabra, K.; Chaudhary, R.; Sawhney, R.L. Treatment of hazardous organic and inorganic compounds through aqueous-phase photocatalysis: A review. Ind. Eng. Chem. Res. 2004, 43, 7683-7696. [CrossRef]

18. Yong, X.; Schoonen, M.A. The absolute energy positions of conduction and valence bands of selected semiconducting minerals. Am. Mineral. 2000, 85, 543-556.

19. Fox, M.A.; Dulay, M.T. Heterogeneous photocatalysis. Chem. Rev. 1993, 93, 341-357. [CrossRef]

20. Demeestere, K.; Dewulf, J.; Van Langenhove, H. Heterogeneous photocatalysis as an advanced oxidation process for the abatement of chlorinated, monocyclic aromatic and sulfurous volatile organic compounds in air: State of the art. Crit. Rev. Environ. Sci. Technol. 2007, 37, 489-538. [CrossRef]

21. Fujishima, A.; Rao, T.N.; Tryk, D.A. Titanium dioxide photocatalysis. J. Photochem. Photobiol. C 2000, 1, 1-21. [CrossRef]

22. Nakata, K.; Fujishima, A. $\mathrm{TiO}_{2}$ photocatalysis: Design and applications. J. Photochem. Photobiol. C 2012, 13, 169-189. [CrossRef]

23. Schneider, J.; Matsuoka, M.; Takeuchi, M.; Zhang, J.; Horiuchi, Y.; Anpo, M.; Bahnemann, D.W. Understanding TiO 2 photocatalysis: Mechanisms and materials. Chem. Rev. 2014, 114, 9919-9986. [CrossRef]

24. Vaiano, V.; Matarangolo, M.; Sacco, O. UV-LEDs floating-bed photoreactor for the removal of caffeine and paracetamol using ZnO supported on polystyrene pellets. Chem. Eng. J. 2018, 350, 703-713. [CrossRef]

25. Xu, T.; Zhang, L.; Cheng, H.; Zhu, Y. Significantly enhanced photocatalytic performance of ZnO via graphene hybridization and the mechanism study. Appl. Cat. B 2011, 101, 382-387. [CrossRef]

26. Baeck, S.H.; Choi, K.S.; Jaramillo, T.F.; Stucky, G.D.; McFarland, E.W. Enhancement of photocatalytic and electrochromic properties of electrochemically fabricated mesoporous $\mathrm{WO}_{3}$ thin films. Adv. Mater. 2003, 15, 1269-1273. [CrossRef]

27. Chen, D.; Ye, J. Hierarchical WO3 hollow shells: Dendrite, sphere, dumbbell, and their photocatalytic properties. Adv. Funct. Mater. 2008, 18, 1922-1928. [CrossRef]

28. Cao, S.W.; Zhu, Y.J. Hierarchically nanostructured $\alpha-\mathrm{Fe}_{2} \mathrm{O}_{3}$ hollow spheres: Preparation, growth mechanism, photocatalytic property, and application in water treatment. J. Phys. Chem. C 2008, 112, 6253-6257. [CrossRef]

29. Mishra, M.; Chun, D.M. $\alpha$-Fe2O3 as a photocatalytic material: A review. Appl. Cat. A 2015, 498, 126-141. [CrossRef]

30. Ji, P.; Zhang, J.; Chen, F.; Anpo, M. Study of adsorption and degradation of acid orange 7 on the surface of CeO2 under visible light irradiation. Appl. Cat. B 2009, 85, 148-154. [CrossRef]

31. Primo, A.; Marino, T.; Corma, A.; Molinari, R.; García, H. Efficient visible-light photocatalytic water splitting by minute amounts of gold supported on nanoparticulate CeO2 obtained by a biopolymer templating method. J. Am. Chem. Soc. 2011, 133, 6930-6933. [CrossRef] [PubMed]

32. Chithambararaj, A.; Sanjini, N.S.; Velmathi, S.; Chandra Bose, A. Preparation of h-MoO3 and $\alpha$-MoO 3 nanocrystals: Comparative study on photocatalytic degradation of methylene blue under visible light irradiation. Phys. Chem. Chem. Phys. 2013, 15, 14761-14769. [CrossRef]

33. Szkoda, M.; Trzciński, K.; Nowak, A.P.; Gazda, M.; Sawczak, M.; Lisowska-Oleksiak, A. The effect of morphology and crystalline structure of $\mathrm{Mo} / \mathrm{MoO}_{3}$ layers on photocatalytic degradation of water organic pollutants. Mater. Chem. Phys. 2020, 248. [CrossRef]

34. Gionco, C.; Paganini, M.C.; Giamello, E.; Sacco, O.; Vaiano, V.; Sannino, D. Rare earth oxides in zirconium dioxide: How to turn a wide band gap metal oxide into a visible light active photocatalyst. J. Energy Chem. 2017, 26, 270-276. [CrossRef]

35. Gao, Y.; Zhang, J.; Jia, X.; Wang, J.; Chen, Z.; Xu, Y. Reactant effect on visible-light driven photocatalytic performance of sol-gel derived tetragonal $\mathrm{ZrO}_{2}$ nanoparticles. Mater. Res. Bull. 2017, 93, 264-269. [CrossRef]

36. Elango, G.; Roopan, S.M. Efficacy of SnO2 nanoparticles toward photocatalytic degradation of methylene blue dye. J. Photochem. Photobiol. B 2016, 155, 34-38. [CrossRef] 
37. Raziq, F.; Qu, Y.; Humayun, M.; Zada, A.; Yu, H.; Jing, L. Synthesis of $\mathrm{SnO}_{2}$ / B-P codoped g- $\mathrm{C}_{3} \mathrm{~N}_{4}$ nanocomposites as efficient cocatalyst-free visible-light photocatalysts for $\mathrm{CO}_{2}$ conversion and pollutant degradation. Appl. Cat. B 2017, 201, 486-494. [CrossRef]

38. Xu, Y.; Zhao, W.; Xu, R.; Shi, Y.; Zhang, B. Synthesis of ultrathin CdS nanosheets as efficient visible-light-driven water splitting photocatalysts for hydrogen evolution. Chem. Commun. 2013, 49, 9803-9805. [CrossRef] [PubMed]

39. Zhu, H.; Jiang, R.; Xiao, L.; Chang, Y.; Guan, Y.; Li, X.; Zeng, G. Photocatalytic decolorization and degradation of Congo Red on innovative crosslinked chitosan/nano-CdS composite catalyst under visible light irradiation. J. Hazard. Mater. 2009, 169, 933-940. [CrossRef]

40. Vaiano, V.; Sacco, O.; Sannino, D.; Ciambelli, P. Process intensification in the removal of organic pollutants from wastewater using innovative photocatalysts obtained coupling Zinc Sulfide based phosphors with nitrogen doped semiconductors. J. Clean. Prod. 2015, 100, 208-211. [CrossRef]

41. Sharma, M.; Jain, T.; Singh, S.; Pandey, O.P. Photocatalytic degradation of organic dyes under UV-Visible light using capped ZnS nanoparticles. Sol. Energy 2012, 86, 626-633. [CrossRef]

42. Tuncer, M.; Ozdemir, B. Photocatalytic activity of TiO2 powders synthesized by supercritical gas antisolvent method. Acta Phys. Pol. A 2014, 125, 608-610. [CrossRef]

43. Da Silva, E.P.; Winkler, M.E.G.; Giufrida, W.M.; Cardozo-Filho, L.; Alonso, C.G.; Lopes, J.B.O.; Rubira, A.F.; Silva, R. Effect of phase composition on the photocatalytic activity of titanium dioxide obtained from supercritical antisolvent. J. Colloid Interface Sci. 2019, 535, 245-254. [CrossRef]

44. Marin, R.P.; Ishikawa, S.; Bahruji, H.; Shaw, G.; Kondrat, S.A.; Miedziak, P.J.; Morgan, D.J.; Taylor, S.H.; Bartley, J.K.; Edwards, J.K.; et al. Supercritical antisolvent precipitation of $\mathrm{TiO}_{2}$ with tailored anatase/rutile composition for applications in redox catalysis and photocatalysis. Appl. Cat. A 2015, 504, 62-73. [CrossRef]

45. Franco, P.; Sacco, O.; De Marco, I.; Vaiano, V. Zinc oxide nanoparticles obtained by supercritical antisolvent precipitation for the photocatalytic degradation of crystal violet dye. Catalysts 2019, 9, 346. [CrossRef]

46. Franco, P.; Sacco, O.; De Marco, I.; Sannino, D.; Vaiano, V. Photocatalytic Degradation of Eriochrome Black-T Azo Dye Using Eu-Doped ZnO Prepared by Supercritical Antisolvent Precipitation Route: A Preliminary Investigation. Top. Catal. 2020, 63, 1193-1205. [CrossRef]

47. Kaneco, S.; Kurimoto, H.; Shimizu, Y.; Ohta, K.; Mizuno, T. Photocatalytic reduction of $\mathrm{CO}_{2}$ using TiO 2 powders in supercritical fluid CO2. Energy 1999, 24, 21-30. [CrossRef]

48. Hirakawa, T.; Whitesell, J.K.; Fox, M.A. Effect of temperature and pressure in the photocatalytic oxidation of n-octanol on partially desilanized hydrophobic $\mathrm{TiO}_{2}$ suspended in aerated supercritical $\mathrm{CO}_{2}$. J. Phys. Chem. B 2004, 108, 10213-10218. [CrossRef]

49. Li, H.; Sunol, S.G.; Sunol, A.K. Development of titanium-dioxide-based aerogel catalyst with tunable nanoporosity and photocatalytic activity. Nanotechnology 2012, 23. [CrossRef] [PubMed]

50. Wu, C.-M.; Peng, R.; Dimitrijevic, N.M.; Rajh, T.; Koodali, R.T. Preparation of $\mathrm{TiO}_{2}-\mathrm{SiO}_{2}$ aperiodic mesoporous materials with controllable formation of tetrahedrally coordinated Ti4+ ions and their performance for photocatalytic hydrogen production. Int. J. Hydrog. Energy 2014, 39, 127-136. [CrossRef]

51. Dagan, G.; Tomkiewicz, M. Titanium dioxide aerogels for photocatalytic decontamination of aquatic environments. J. Phys. Chem. 1993, 97, 12651-12655. [CrossRef]

52. Parale, V.G.; Kim, T.; Lee, K.-Y.; Phadtare, V.D.; Dhavale, R.P.; Park, H.-H. Hydrophobic $\mathrm{TiO}_{2}-\mathrm{SiO}_{2}$ composite aerogels synthesized via in situ epoxy-ring opening polymerization and sol-gel process for enhanced degradation activity. Ceram. Int. 2020, 46, 4939-4946. [CrossRef]

53. Parale, V.G.; Kim, T.; Phadtare, V.D.; Yadav, H.M.; Park, H.-H. Enhanced photocatalytic activity of a mesoporous TiO 2 aerogel decorated onto three-dimensional carbon foam. J. Mol. Liq. 2019, 277, 424-433. [CrossRef]

54. Parale, V.G.; Kim, T.; Phadtare, V.D.; Han, W.; Lee, K.-Y.; Choi, H.; Kim, Y.; Yadav, H.M.; Park, H.-H. SnO 2 aerogel deposited onto polymer-derived carbon foam for environmental remediation. J. Mol. Liq. 2019, 287, 110990. [CrossRef]

55. Leitner, W. Supercritical carbon dioxide as a green reaction medium for catalysis. Acc. Chem. Res. 2002, 35, 746-756. [CrossRef]

56. Ramsey, E.; Qiubai, S.; Zhang, Z.; Zhang, C.; Wei, G. Mini-Review: Green sustainable processes using supercritical fluid carbon dioxide. J. Environ. Sci. 2009, 21, 720-726. [CrossRef]

57. Song, C. Global challenges and strategies for control, conversion and utilization of $\mathrm{CO}_{2}$ for sustainable development involving energy, catalysis, adsorption and chemical processing. Catal. Today 2006, 115, 2-32. [CrossRef]

58. Bozbağ, S.E.; Erkey, C. Supercritical deposition: Current status and perspectives for the preparation of supported metal nanostructures. J. Supercrit. Fluids 2015, 96, 298-312. [CrossRef]

59. Barim, S.B.; Uzunlar, E.; Bozbag, S.E.; Erkey, C. Review-Supercritical Deposition: A Powerful Technique for Synthesis of Functional Materials for Electrochemical Energy Conversion and Storage. J. Electrochem. Soc. 2020, 167. [CrossRef]

60. Watkins, J.J.; McCarthy, T.J. Polymer/Metal Nanocomposite Synthesis in Supercritical CO2. Chem. Mater. 1995, 7, 1991-1994. [CrossRef]

61. Horibe, T.; Kondo, H.; Ishikawa, K.; Kano, H.; Sekine, M.; Hiramatsu, M.; Hori, M. Supercritical fluid deposition of high-density nanoparticles of photocatalytic $\mathrm{TiO}_{2}$ on carbon nanowalls. Appl. Phys. Express 2013, 6. [CrossRef] 
62. Liu, C.; Lin, X.; Li, Y.; Xu, P.; Li, M.; Chen, F. Enhanced photocatalytic performance of mesoporous $\mathrm{TiO}_{2}$ coated SBA-15 nanocomposites fabricated through a novel approach: Supercritical deposition aided by liquid-crystal template. Mater. Res. Bull. 2016, 75, 25-34. [CrossRef]

63. Kashiwaya, S.; Aymonier, C.; Majimel, J.; Olivier, C.; Klein, A.; Jaegermann, W.; Toupance, T. Supercritical $\mathrm{CO}_{2}$-assisted deposition of $\mathrm{NiO}$ on (101)-anatase-TiO2 for efficient facet engineered photocatalysts. New J. Chem. 2018, 42, 18649-18658. [CrossRef]

64. Sun, L.; Han, P.; Tang, S. Preparation of Ordered Mesoporous Alumina Supported-ZnO/NiO Nanocomposite Using Supercritical Carbon Dioxide Impregnation and Its Photocatalytic Performance. ChemNanoMat 2019, 5, 723-728. [CrossRef]

65. Chang, F.; Wang, G.; Xie, Y.; Zhang, M.; Zhang, J.; Yang, H.-J.; Hu, X. Synthesis of TiO2 nanoparticles on mesoporous aluminosilicate Al-SBA-15 in supercritical CO2 for photocatalytic decolorization of methylene blue. Ceram. Int. 2013, 39, 3823-3829. [CrossRef]

66. Franco, P.; Martino, M.; Palma, V.; Scarpellini, A.; De Marco, I. Pt on SAS-CeO2 nanopowder as catalyst for the CO-WGS reaction. Int. J. Hydrog. Energy 2018, 43, 19965-19975. [CrossRef]

67. Marin, R.P.; Kondrat, S.A.; Davies, T.E.; Morgan, D.J.; Enache, D.I.; Combes, G.B.; Taylor, S.H.; Bartley, J.K.; Hutchings, G.J. Novel cobalt zinc oxide Fischer-Tropsch catalysts synthesised using supercritical anti-solvent precipitation. Catal. Sci. Technol. 2014, 4, 1970-1978. [CrossRef]

68. Jiang, H.; Zhang, L.; Zhao, J.; Li, Y.; Zhang, M. Study on $\mathrm{MnO}$ x-FeO y composite oxide catalysts prepared by supercritical antisolvent process for low-temperature selective catalytic reduction of NO x. J. Mater. Res. 2016, 31, 702. [CrossRef]

69. Tang, Z.-R.; Edwards, J.K.; Bartley, J.K.; Taylor, S.H.; Carley, A.F.; Herzing, A.A.; Kiely, C.J.; Hutchings, G.J. Nanocrystalline cerium oxide produced by supercritical antisolvent precipitation as a support for high-activity gold catalysts. J. Catal. 2007, 249, 208-219. [CrossRef]

70. Vaiano, V.; Matarangolo, M.; Sacco, O.; Sannino, D. Photocatalytic treatment of aqueous solutions at high dye concentration using praseodymium-doped ZnO catalysts. Appl. Cat. B 2017, 209, 621-630. [CrossRef]

71. Ong, C.B.; Ng, L.Y.; Mohammad, A.W. A review of ZnO nanoparticles as solar photocatalysts: Synthesis, mechanisms and applications. Renew. Sustain. Energy Rev. 2018, 81, 536-551. [CrossRef]

72. Štrbac, D.; Aggelopoulos, C.A.; Štrbac, G.; Dimitropoulos, M.; Novaković, M.; Ivetić, T.; Yannopoulos, S.N. Photocatalytic degradation of Naproxen and methylene blue: Comparison between ZnO, TiO2 and their mixture. Process Saf. Environ. 2018, 113, 174-183. [CrossRef]

73. Sui, R.; Charpentier, P. Synthesis of metal oxide nanostructures by direct sol-gel chemistry in supercritical fluids. Chem. Rev. 2012, 112, 3057-3082. [CrossRef]

74. Tadros, M.E.; Adkins, C.L.J.; Russick, E.M.; Youngman, M.P. Synthesis of titanium dioxide particles in supercritical CO2. J. Supercrit. Fluids 1996, 9, 172-176. [CrossRef]

75. Reverchon, E.; Caputo, G.; Correra, S.; Cesti, P. Synthesis of titanium hydroxide nanoparticles in supercritical carbon dioxide on the pilot scale. J. Supercrit. Fluids 2003, 26, 253-261. [CrossRef]

76. Jensen, H.; Joensen, K.D.; Iversen, S.B.; Søgaard, E.G. Low Temperature Synthesis of Metal Oxides by a Supercritical Seed Enhanced Crystallization (SSEC) Process. Ind. Eng. Chem. Res. 2006, 45, 3348-3353. [CrossRef]

77. Simonsen, M.E.; Jensen, H.; Li, Z.; Søgaard, E.G. Surface properties and photocatalytic activity of nanocrystalline titania films. J. Photochem. Photobiol. A 2008, 200, 192-200. [CrossRef]

78. Camarillo, R.; Rizaldos, D.; Jiménez, C.; Martínez, F.; Rincón, J. Enhancing the photocatalytic reduction of $\mathrm{CO}_{2}$ with undoped and $\mathrm{Cu}$-doped $\mathrm{TiO}_{2}$ nanofibers synthesized in supercritical medium. J. Supercrit. Fluids 2019, 147, 70-80. [CrossRef]

79. D'Elia, D.; Beauger, C.; Hochepied, J.F.; Rigacci, A.; Berger, M.H.; Keller, N.; Keller-Spitzer, V.; Suzuki, Y.; Valmalette, J.C.; Benabdesselam, M.; et al. Impact of three different $\mathrm{TiO}_{2}$ morphologies on hydrogen evolution by methanol assisted water splitting: Nanoparticles, nanotubes and aerogels. Int. J. Hydrog. Energy 2011, 36, 14360-14373. [CrossRef]

80. Chen, L.; Zhu, J.; Liu, Y.M.; Cao, Y.; Li, H.X.; He, H.Y.; Dai, W.L.; Fan, K.N. Photocatalytic activity of epoxide sol-gel derived titania transformed into nanocrystalline aerogel powders by supercritical drying. J. Mol. Catal. A Chem. 2006, 255, 260-268. [CrossRef]

81. Boujday, S.; Wünsch, F.; Portes, P.; Bocquet, J.-F.; Colbeau-Justin, C. Photocatalytic and electronic properties of TiO 2 powders elaborated by sol-gel route and supercritical drying. Sol. Energy Mater. Sol. Cells 2004, 83, 421-433. [CrossRef]

82. Lin, C.C.; Wei, T.Y.; Lee, K.T.; Lu, S.Y. Titania and Pt/titania aerogels as superior mesoporous structures for photocatalytic water splitting. J. Mater. Chem. 2011, 21, 12668-12674. [CrossRef]

83. Kim, W.-I.; Suh, D.J.; Park, T.-J.; Hong, I.-K. Photocatalytic degradation of methanol on titania and titania-silica aerogels prepared by non-alkoxide sol-gel route. Top. Catal. 2007, 44, 499-505. [CrossRef]

84. Mumin, M.A.; Moula, G.; Charpentier, P.A. Supercritical $\mathrm{CO}_{2}$ synthesized $\mathrm{TiO}_{2}$ nanowires covalently linked with core-shell CdS-ZnS quantum dots: Enhanced photocatalysis and stability. RSC Adv. 2015, 5, 67767-67779. [CrossRef]

85. Bartkova, H.; Kluson, P.; Bartek, L.; Drobek, M.; Cajthaml, T.; Krysa, J. Photoelectrochemical and photocatalytic properties of titanium (IV) oxide nanoparticulate layers. Thin Solid Films 2007, 515, 8455-8460. [CrossRef]

86. Ding, Z.; Zhu, H.Y.; Lu, G.Q.; Greenfield, P.F. Photocatalytic properties of titania pillared clays by different drying methods. J. Colloid Interface Sci. 1999, 209, 193-199. [CrossRef]

87. Buaki-Sogo, M.; Serra, M.; Primo, A.; Alvaro, M.; Garcia, H. Alginate as template in the preparation of active titania photocatalysts. ChemCatChem 2013, 5, 513-518. [CrossRef] 
88. Puskelova, J.; Baia, L.; Vulpoi, A.; Baia, M.; Antoniadou, M.; Dracopoulos, V.; Stathatos, E.; Gabor, K.; Pap, Z.; Danciu, V.; et al. Photocatalytic hydrogen production using $\mathrm{TiO}_{2}$-Pt aerogels. Chem. Eng. J. 2014, 242, 96-101. [CrossRef]

89. Sacco, O.; Vaiano, V.; Daniel, C.; Navarra, W.; Venditto, V. Removal of phenol in aqueous media by $\mathrm{N}-\mathrm{doped} \mathrm{TiO}_{2}$ based photocatalytic aerogels. Mat. Sci. Semicon. Proc. 2018, 80, 104-110. [CrossRef]

90. Popa, M.; Diamandescu, L.; Vasiliu, F.; Teodorescu, C.M.; Cosoveanu, V.; Baia, M.; Feder, M.; Baia, L.; Danciu, V. Synthesis, structural characterization, and photocatalytic properties of iron-doped $\mathrm{TiO}_{2}$ aerogels. J. Mater. Sci. 2009, 44, 358-364. [CrossRef]

91. Lucky, R.A.; Charpentier, P.A. N-doped $\mathrm{ZrO}_{2} / \mathrm{TiO}_{2}$ bimetallic materials synthesized in supercritical $\mathrm{CO}_{2}: \mathrm{Morphology}$ and photocatalytic activity. Appl. Cat. B 2010, 96, 516-523. [CrossRef]

92. Yoda, S.; Suh, D.J.; Sato, T. Adsorption and photocatalytic decomposition of benzene using silica-titania and titania aerogels: Effect of supercritical drying. J. Solgel Sci. Technol. 2001, 22, 75-81. [CrossRef]

93. Cao, S.; Yeung, K.L.; Yue, P.L. Preparation of freestanding and crack-free titania-silica aerogels and their performance for gas phase, photocatalytic oxidation of VOCs. Appl. Cat. B 2006, 68, 99-108. [CrossRef]

94. Cao, S.; Yeung, K.L.; Yue, P.L. An investigation of trichloroethylene photocatalytic oxidation on mesoporous titania-silica aerogel catalysts. Appl. Cat. B 2007, 76, 64-72. [CrossRef]

95. Justh, N.; Mikula, G.J.; Bakos, L.P.; Nagy, B.; László, K.; Parditka, B.; Erdélyi, Z.; Takáts, V.; Mizsei, J.; Szilágyi, I.M. Photocatalytic properties of $\mathrm{TiO}_{2} @$ polymer and $\mathrm{TiO}_{2} @$ carbon aerogel composites prepared by atomic layer deposition. Carbon 2019, 147, 476-482. [CrossRef]

96. Sacco, O.; Vaiano, V.; Daniel, C.; Navarra, W.; Venditto, V. Highly robust and selective system for water pollutants removal: How to transform a traditional photocatalyst into a highly robust and selective system for water pollutants removal. Nanomaterials 2019, 9, 1509. [CrossRef]

97. Kim, B.; Keum, Y.; Chen, Y.-P.; Oh, H.S.; Lee, J.Y.; Park, J. Stimuli-Responsive Ti-Organic Gels and Aerogels Derived from Ti-Oxo Clusters: Hierarchical Porosity and Photocatalytic Activity. Inorg. chem. 2019, 58, 15936-15941. [CrossRef]

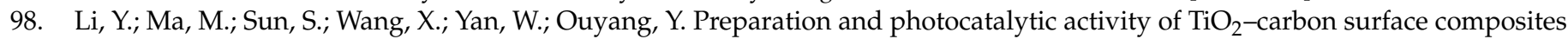
by supercritical pretreatment and sol-gel process. Catal. Commun. 2008, 9, 1583-1587. [CrossRef]

99. Zeng, M.-x.; Li, Y.-j.; Wei, C.; LI, L.-y. Photocatalytic activity and kinetics for acid yellow degradation over surface composites of TiO2-coated activated carbon under different photocatalytic conditions. Trans. Nonferrous Met. Soc. 2013, 23, $1019-1027$. [CrossRef]

100. You-ji, L.; Wei, C. Photocatalytic degradation of Rhodamine B using nanocrystalline $\mathrm{TiO}_{2}$-zeolite surface composite catalysts: Effects of photocatalytic condition on degradation efficiency. Catal. Sci. Technol. 2011, 1, 802-809. [CrossRef]

101. Wang, K.; Yao, B.; Morris, M.A.; Holmes, J.D. Supercritical fluid processing of thermally stable mesoporous titania thin films with enhanced photocatalytic activity. Chem. Mater. 2005, 17, 4825-4831. [CrossRef]

102. Zhang, F.; Zhang, B.; Feng, J.; Tan, X.; Liu, L.; Liu, L.; Han, B.; Zheng, L.; Zhang, J.; Tai, J. Highly mesoporous Ru-MIL-125-NH2 produced by supercritical fluid for efficient photocatalytic hydrogen production. ACS Appl. Energy Mater. 2019, 2, 4964-4970. [CrossRef]

103. Marković, D.; Milovanović, S.; Radovanović, Ž.; Zizovic, I.; Šaponjić, Z.; Radetić, M. Floating photocatalyst based on poly ( $\varepsilon$-caprolactone) foam and $\mathrm{TiO}_{2}$ nanoparticles for removal of textile dyes. Fiber Polym. 2018, 19, 1219-1227. [CrossRef]

104. Camarillo, R.; Toston, S.; Martinez, F.; Jimenez, C.; Rincon, J. Enhancing the photocatalytic reduction of CO2 through engineering of catalysts with high pressure technology: $\mathrm{Pd} / \mathrm{TiO}_{2}$ photocatalysts. J. Supercrit. Fluids 2017, 123, 18-27. [CrossRef]

105. Alonso, E.; Montequi, I.; Cocero, M. Effect of synthesis conditions on photocatalytic activity of $\mathrm{TiO}_{2}$ powders synthesized in supercritical CO2. J. Supercrit. Fluids 2009, 49, 233-238. [CrossRef]

106. Rodríguez, V.; Camarillo, R.; Martínez, F.; Jiménez, C.; Rincón, J. $\mathrm{CO}_{2}$ photocatalytic reduction with $\mathrm{CNT} / \mathrm{TiO}_{2}$ based nanocomposites prepared by high-pressure technology. J. Supercrit. Fluids 2020, 163, 104876. [CrossRef]

107. Camarillo, R.; Toston, S.; Martinez, F.; Jimenez, C.; Rincon, J. Preparation of $\mathrm{TiO}_{2}$-based catalysts with supercritical fluid technology: Characterization and photocatalytic activity in $\mathrm{CO}_{2}$ reduction. J. Chem. Technol. Biotechnol. 2017, 92, 1710-1720. [CrossRef]

108. Grills, D.C.; Fujita, E. New directions for the photocatalytic reduction of $\mathrm{CO}_{2}$ : Supramolecular, scCO2 or biphasic ionic liquid$\mathrm{scCO}_{2}$ systems. J. Phys. Chem. Lett. 2010, 1, 2709-2718. [CrossRef]

109. Chiu, W.-T.; Chen, C.-Y.; Chang, T.-F.M.; Tahara, Y.; Hashimoto, T.; Kurosu, H.; Sone, M. Fabrication and photocatalytic performance of $\mathrm{Au} / \mathrm{ZnO}$ layered structure on silk textile for flexible device applications. Electrochim. Acta 2017, $253,39-46$. [CrossRef]

110. Ren, Y.; Li, C.; Xu, Q.; Yan, J.; Li, Y.; Yuan, P.; Xia, H.; Niu, C.; Yang, X.; Jia, Y. Two-dimensional amorphous heterostructures of $\mathrm{Ag} / \mathrm{a}-\mathrm{WO}_{3}$-x for high-efficiency photocatalytic performance. Appl. Cat. B 2019, 245, 648-655. [CrossRef]

111. Haldorai, Y.; Shim, J.-J. Supercritical fluid mediated synthesis of highly exfoliated graphene/ZnO composite for photocatalytic hydrogen production. Mater. Lett. 2014, 133, 24-27. [CrossRef] 